Review Article

\title{
Reviewing the characteristics of BRCA and PALB2-related cancers in the precision medicine era
}

\author{
Gabriel S. Macedo ${ }^{1,2}$ iD, Barbara Alemar ${ }^{1}$ and Patricia Ashton-Prolla ${ }^{1,2}$ \\ ${ }^{1}$ Post-Graduate Program in Genetics and Molecular Biology, Universidade Federal do Rio Grande do Sul \\ (UFRGS), Porto Alegre, RS, Brazil. \\ ${ }^{2}$ Precision Medicine Program, Hospital de Clínicas de Porto Alegre, Porto Alegre, RS, Brazil.
}

\begin{abstract}
Germline mutations in BRCA1 and BRCA2 (BRCA) genes confer high risk of developing cancer, especially breast and ovarian tumors. Since the cloning of these tumor suppressor genes over two decades ago, a significant amount of research has been done. Most recently, monoallelic loss-of-function mutations in PALB2 have also been shown to increase the risk of breast cancer. The identification of BRCA1, BRCA2 and PALB2 as proteins involved in DNA double-strand break repair by homologous recombination and of the impact of complete loss of BRCA1 or BRCA2 within tumors have allowed the development of novel therapeutic approaches for patients with germline or somatic mutations in said genes. Despite the advances, especially in the clinical use of PARP inhibitors, key gaps remain. Now, new roles for BRCA1 and BRCA2 are emerging and old concepts, such as the classical two-hit hypothesis for tumor suppression, have been questioned, at least for some BRCA functions. Here aspects regarding cancer predisposition, cellular functions, histological and genomic findings in BRCA and PALB2-related tumors will be presented, in addition to an up-to-date review of the evolution and challenges in the development and clinical use of PARP inhibitors.
\end{abstract}

Keywords: BRCA1, BRCA2, homologous recombination, cancer predisposition, PARP inhibitors.

Received: May 15, 2018; Accepted: October 24, 2018.

\section{BRCA1, BRCA2 and PALB2 genes: mutations and associated phenotypes}

Hereditary breast and ovarian cancer (HBOC) syndrome is a highly penetrant autosomal dominant disorder accounting for $5-7 \%$ of breast cancers (BCs) and $8-13 \%$ of epithelial ovarian cancers (EOCs). It is caused mainly by germline mutations in BRCA1 and/or BRCA2 (collectively "BRCA" hereafter) (Liu et al., 2012; Roy,et al., 2012; Dai et al., 2018). In $B R C A 1$ mutation carriers, the average cumulative risks of breast and ovarian tumors by the age of 70 years is $65 \%$ and $39 \%$, respectively, whereas in BRCA2 mutation carriers the corresponding estimates are $45 \%$ and $11 \%$ (Antoniou et al., 2003). By the age of 80, the cumulative risks of breast and ovarian cancer increase, respectively, to $72 \%$ and $44 \%$ for BRCAl carriers, and $69 \%$ and $17 \%$ for $B R C A 2$ carriers (Kuchenbaecker et al., 2017). Additionally, women who carry $B R C A 1$ germline mutations also have an increased risk of developing fallopian tube and peritoneal cancers (Brose et al., 2002; Finch et al., 2006). Carriers of BRCA1 or BRCA2 mutations may also be in risk for prostate

Send correspondence to Gabriel de Souza Macedo. Laboratório de Medicina Genômica, Centro de Pesquisa Experimental, Hospital de Clínicas de Porto Alegre, Rua Ramiro Barcelos, 2350, 90035903 Porto Alegre, RS, Brazil. E-mail: gmacedo@ hcpa.edu.br and pancreatic cancer (Levy-Lahad and Friedman, 2007; Consortium, 1999; Thompson et al., 2002; Ferrone et al., 2009). Recently, monoallelic loss-of-function mutations in PALB2 (Partner and Localizer of BRCA2) were found to confer predisposition to cancer, with a mean risk of $\mathrm{BC}$ in females of 35\% by age 70 (Rahman et al., 2007; Antoniou et al., 2014;). Couch et al. (2017) showed that pathogenic mutations in PALB2 are in fact associated with a high-risk of $\mathrm{BC}$ (odds ratio 7.5). Based on data from different populations, PALB2 germline mutations appear to account for approximately $0.7-1.1 \%$ of all familial aggregation of $\mathrm{BC}$ (Rahman et al., 2007; Buys et al., 2017; Eliade et al., 2017). $P A L B 2$ has also been reported as a susceptibility gene for pancreatic cancer (Jones et al., 2009b; Tischkowitz et al., 2009; Slater et al., 2010).

Germline BRCA1, BRCA2 and PALB2 mutations are also associated with an increased risk of developing male breast cancer (MBC) (Thompson et al., 2002; Levy-Lahad and Friedman, 2007; Rahman et al., 2007). Although corresponding to less than $1 \%$ of all $\mathrm{BC}$ cases, a significant proportion of MBCs arise in a setting of familial BC (Anderson and Badzioch, 1992; Hemminki and Vaittinen, 1999; Weiss et al., 2005). Pathogenic germline mutations in BRCA2 and PALB2 have been found in 5-40\% (Thorlacius et al., 1997; Basham et al., 2002; Ding et al., 2011) and 1-2\% (Ding et 
al., 2011) of all MBCs, respectively. However, the association between BRCA1 germline mutations and $\mathrm{MBC}$ is not well established, although several studies have demonstrated that the BRCA1 germline mutations may contribute to a small fraction of MBC cases (Csokay et al., 1999; Sverdlov et al., 2000; Ottini et al., 2009). It was also reported BRCA germline mutations in $28 \%$ of men with $\mathrm{BC}$, of which a substantial proportion (8 of 22) occurred in BRCAl (Frank et al., 2002).

Different from most HBOC cases, in which monoallelic germline mutations are associated to increased adultonset predisposition to several tumors, biallelic germline loss-of-function mutations in a set of DNA repair genes, including BRCA1, BRCA2 and PALB2, are associated to a distinct phenotype, characterizing subgroups of Fanconi Anemia (FA) (Howlett et al., 2002; Reid et al., 2007; Sawyer et al., 2015). FA is a rare recessive genetically heterogeneous chromosomal instability disorder characterized by congenital and developmental abnormalities and a high predisposition to cancers (Tischkowitz and Hodgson, 2003). FA is divided into several complementation groups according to the mutated gene (Mathew, 2006). Biallelic mutations in $B R C A 2$ (also known as FANCD1) are identified in around $3-5 \%$ of FA cases and are associated with a high risk of aggressive embryonal tumors in early childhood stages (mostly medulloblastomas and nephroblastomas) and/or acute leukemia (Reid et al., 2005; Meyer et al., 2014). The cumulative probability of any tumor in these patients was found to be of $97 \%$ by age 5.2 years (Alter et al., 2007). Biallelic PALB2 (also referred as $F A N C N$ ) pathogenic mutations were identified in families affected with FA and childhood cancer, characterizing a new subtype of the disease (Reid et al., 2007). More recently, biallelic BRCA1 mutations have also been shown to cause a FA-like phenotype (Sawyer et al., 2015; Freire et al., 2018). It has been proposed that patients with two nonsense mutations may survive as the result of naturally occurring alternative splicing that yields a short but partially functional BRCA1 protein (Seo et al., 2018).

\section{BRCA1, BRCA2 and PALB2 mutations}

Located on the long arm of chromosome 17 at $17 \mathrm{q} 21$ (Miki et al., 1994), the BRCAl tumor suppressor gene is composed by 23 exons encoding for a protein of 1863 amino acids (Connor et al., 1997; Teng et al., 2008). BRCA2 maps to chromosome 13 (13q12.3) (Connor et al., 1997) and consists of 27 exons coding for 3418 amino acids (Tavtigian et al., 1996). The largest exons in BRCA1 and BRCA2 are exons 10 and 11 , respectively, which harbors the majority of mutations identified in patients, most of which are frameshift mutations resulting in missing or nonfunctional proteins (Al-Mulla et al., 2009).

The overall population prevalence of $B R C A 1$ and $B R C A 2$ mutation carriers is estimated to be 1 in 400 to 1 in 800 , respectively, but varies considerably according to the ethnic group (Ford et al., 1995; Whittemore et al., 1997). For instance, in the Ashkenazi Jewish population two common mutations in BRCA1 (c.68_69delAG, formerly known as $185 \mathrm{delAG}$, and c.5266dupC, also known as 5382insC) and one common mutation in BRCA2 (c.5946delT, formerly known as 6174delT) are highly prevalent (approximately 2\%) (Struewing et al., 1997; Gabai-Kapara et al., 2014). The most common types of deleterious mutations found in $B R C A 1$ and $B R C A 2$ are small frameshift deletions or insertions, nonsense, and splice site mutations (Borg et al., 2010). Interestingly, the genomic regions of both $B R C A 1$ and $B R C A 2$ genes are composed by a very high density of repetitive DNA elements, comprising approximately $47 \%$ of BRCA1 (42\% Alu sequences and 5\% non-Alu repeats) and BRCA2 (20\% Alu and 27\% LINE and MER repetitive DNA) sequence (Welcsh and King, 2001). Given these characteristics, it is not surprising that Alu-mediated genomic rearrangements within both genes have been observed (Qian et al., 2017). Nevertheless, large rearrangements have been estimated to occur in $0-40 \%$ of carriers, depending of the population, and should always be investigated when initial sequencing analysis not sensitive for their detection are reported as negative (Ewald et al., 2009). More recently, due to the possibility of identification of compound heterozygotes, genetic testing guidelines have recommended sequencing and gene rearrangement testing in all suspected cases (NCCN, 2017).

A large number of rare germline variants has been reported throughout both genes according to the Breast Cancer Information Core website (BIC) (approximately 1800 mutations in $B R C A 1$ and 2000 mutations in $B R C A 2$ ), and the majority of those have not been reported as recurrent (Breast Cancer Information Core; http://www.research.nhgri.nih.gov/bic). Moreover, around $15 \%$ of individuals without any clear pathogenic variant in the $B R C A 1$ or $B R C A 2$ genes and about $5-7 \%$ of all individuals who undergo $B R C A 1$ and $B R C A 2$ testing will be found to have a variant of uncertain significance (VUS), which include missense changes, small in-frame deletions or insertions, as well as alterations in non-coding or in untranslated regions (Plon et al., 2008; Ready et al., 2011; Alemar et al., 2017). Identification of VUS has become a huge challenge when tailoring genetic counseling and disease prevention strategies related to HBOC syndrome (Cheon et al., 2014). Some criteria, such as functional assays, have been proposed to ascertain the pathogenicity of $B R C A 1 / B R C A 2$ VUS (Toland and Andreassen, 2017).

The spectrum of $P A L B 2$ mutations is similar to that found in $B R C A 1$ and $B R C A 2$ genes, in which protein truncating mutations are distributed throughout the coding regions. However, in contrast to its partners, there is only a small number of pathogenic (or likely pathogenic) missense mutations in the gene, being the vast majority frameshift and nonsense mutations (Southey et al., 2013). Interestingly, in the Finnish population only one mutation in PALB2 was described (c.1592delT). This founder mutation occurs in $0.2 \%$ of the general population and is associated with a 6-fold increased risk of BC (Erkko et al., 2007, 2008; Haanpää et al., 2013). 


\section{Biological functions and impact of mutations}

\section{BRCA1, BRCA2 and PALB2 functions}

Few years after the discovery of $B R C A 1$ and $B R C A 2$ genes, many studies were able to show aspects regarding the physical and functional interactions made by BRCA proteins in several biological processes, especially in DNA damage response and maintenance of the chromosomal stability (Venkitaraman, 2001; Nielsen et al., 2016). Although BRCA1 and BRCA2 have clearly different biochemical functions, the precise mechanisms by which these proteins protect chromosome integrity are not completely understood. The differences in terms of intracellular localization during the cell cycle, the complexity of partners that have been reported to interact with BRCA proteins, and the dynamic nature of these properties according to cellular signals suggest that BRCA1 and BRCA2 belong to a subset of proteins that work as "hubs" (Venkitaraman, 2014). More recently, the functional interaction of PALB2 and BRCA proteins as well as their role in DNA damage response has been partially described (Xia et al., 2006; Sy et al., 2009).

The protein products of $B R C A 1$ and $B R C A 2$ have been recognized as crucial for an effective DNA repair of double-strand breaks (DSB) (Moynahan et al., 1999, 2001). DSB is one of the most cytotoxic types of DNA damage and it may trigger genome rearrangements and cell death (Stracker et al., 2013). DSB repair is mainly undertaken by homologous recombination (HR) and nonhomologous end-joining (NHEJ), two DNA repair pathways that are differentially regulated depending on the phase of the cell cycle and nature of the damage (Burma et al., 2006; Sonoda et al., 2006; Mao et al., 2008). HR, a vital DNA repair pathway that uses the undamaged sister chromatid to repair replication-associated DSBs, is a commonly error free pathway especially important during the S and G2 phases of the cell cycle. HR involves proteins that can detect broken ends (sensors, e.g ATM/ATR), repair the damage (effectors, e.g BRCA2 and RAD51) and connect both (mediators, e.g CHK2 and BRCA1) (Roy et al., 2012). PALB2 is immediately downstream of BRCA1, being required for efficient DNA repair by HR (Zhang et al., 2009). PALB2 absence prevents recruitment of BRCA2 and RAD51 to the DSB site (Xia et al., 2006; Sy et al., 2009).

In addition to HR, NHEJ DNA repair pathway may be activated as an alternative mechanism of DSB repair (Brandsma and Gent, 2012). NHEJ is active throughout the cell cycle (favored in $\mathrm{G} 1$ ) and promotes direct ligation of the DSB ends, but in an error-prone manner, frequently resulting in small insertions, deletions and translocations (Lieber, 2010). Although there are conflicting results concerning the role of BRCA1 in NHEJ, this DNA repair pathway has been reported to be unaffected in a BRCA1-deficiency context (Baldeyron et al., 2002; Gudmundsdottir and Ashworth 2006). This may be due, at least in part, to the differential involvement of this protein in the NHEJ subpathways. Some studies support the promoting role of BRCA1 in precise NHEJ, while others show a negative regulation (Wang et al.,
2006). So far, it seems that BRCA2 and PALB2 are not required for NHEJ DNA repair (Xia et al., 2001; Metzger et al., 2013).

It is remarkable that BRCA1, BRCA2 and PALB2deficient cells exhibit spontaneously single sister chromatid breaks, quadri and triradial chromosomes, as well as translocations, large deletions, and fusions involving non-homologous chromosomes (Shen et al., 1998; Yu et al., 2000; Moynahan 2002; Nikkilä et al., 2013). Most importantly, DSB seems to be the typical structural aberration found in BRCA-deficient cells, suggesting that HR is important for tumor suppression (Venkitaraman, 2014). Thus, cells that lack BRCA1, BRCA2 or PALB2 repair the lesions by an error-prone mechanism, such as NHEJ (Tutt et al., 2005; Obermeier et al., 2015;). This shift is in agreement with aneuploid features and frequently compromised chromosome segregations found in these cells (Venkitaraman, 2014). Taken together, this data supports the current knowledge that BRCA and PALB2 proteins play important roles in the maintenance of genomic stability, while deficiency of these proteins promotes chromosomal instability and carcinogenesis.

More recently, based on the broad variability of abnormalities found in BRCA knockout and mutated cells, several new functions for $B R C A 1$ and $B R C A 2$ genes have emerged. BRCA1 has been implicated in the mitotic spindle-pole assembly, via BRCA1/BARD1 complex. The potent ubiquitin E3 ligase activity of this interaction seems to be fundamental for TPX2 accumulation, a major spindle organizer. This previously unrecognized function likely contributes to its chromosome stability control and tumor suppression (Joukov et al., 2006). Inactivation of BRCA2 also leads to spindle assembly defects and aneuploidies, suggesting a role of BRCA2 in the spindle assembly checkpoint and kinetochore stability (Choi et al., 2012). Moreover, BRCA2 also seems to protect the length of the nascent strand of DNA from degradation at stalled replication forks, since BRCA2-deficient hamster cells show that newly synthesized DNA strands are substantially shorter compared to wild-type BRCA2 cells (Schlacher et al., 2011). Several other studies have also suggested a role for BRCA proteins in chromatin remodeling (Ye et al., 2001), gene expression (Hill et al., 2014), telomere protection (French et al., 2006; Badie et al., 2010), and heterochromatin maintenance (Zhu et al., 2011). However, whether these emerging BRCA functions are required for tumor suppression is unknown.

\section{The two-hit model of carcinogenesis}

Over 40 years ago, Alfred Knudson proposed a model of carcinogenesis in which biallelic mutations in a tumor suppressor gene are required for tumor development (also called Knudson's “Two Hit” Hypothesis) (Knudson, 1971). Although this has been accepted for many years, recently published data have shown that inactivation of both alleles may not be a rate-limiting step for some tumor suppressor genes (Berger et al., 2011). Haploinsufficiency is one of the 
mechanisms that may explain phenotypes arising in tumors or normal cells heterozygous for such mutations. This phenomenon, characterized by reduction in the gene dosage as a result of a monoallelic mutation, leads to changes of cellular processes that may contribute to tumorigenesis (Santarosa and Ashworth, 2004). In agreement with the Knudson hypothesis, seminal studies in mice models showed that complete BRCA1, BRCA2 and PALB2 deficiency results in early embryonic lethality. Interestingly, BRCA1, BRCA2 and PALB2 heterozygous mice could not be distinguished from wild-type animals, corroborating the classic recessive model for tumor suppression, at least in animal models (Gowen et al., 1996; Sharan et al., 1997; Rantakari et al., 2010).

In contrast to what has been observed in mice, humans heterozygous for pathogenic BRCA1, BRCA2 and PALB2 germline mutations are predisposed to several tumors (Antoniou et al., 2003, 2014; Liu et al., 2012; Roy et al., 2012), and biallelic mutations in these genes result in FA (Howlett et al., 2002; Reid et al., 2007; Sawyer et al., 2015). Although $B R C A 1, B R C A 2$ and PALB2 have been considered bona fide tumor suppressor genes, whose complete loss-of-function due to deletion, mutation, or gene promoter methylation of the wild-type allele is required for carcinogenesis (Narod and Foulkes 2004; Ashworth et al., 2011; Bowman-Colin et al., 2013;), new evidence has challenged this notion and demonstrated that heterozygote mutations in these genes may be sufficient to impact on biological functions. This affects DNA repair and genomic stability function, enabling the development of tumors in humans (Pathania et al., 2014; Sedic et al., 2015). Thus, it is unclear whether inactivation of the wild-type allele is essential for tumor initiation or if that occurs stochastically.

Several studies have shown that although loss of the wild-type allele (loss of heterozygosity, $\mathrm{LOH}$ ) is common in breast tumors from carriers of germline BRCA1 or BRCA2 mutations (BRCA-BCs), not all breast tumors display this feature, suggesting that at least a subset of the BRCA-BCs can develop in the absence of BRCA LOH (Osorio et al., 2002; Palacios et al., 2003; Tung et al., 2010; Stefansson et al., 2011; Martins et al., 2012). Indeed, Maxwell et al. (2017) evaluated $160 B R C A$ germline mutated breast and ovarian tumors and found that while BRCA1-germline mutant breast and ovarian tumors had LOH in $90 \%$ and $93 \%$ of all BRCA1-related cases, respectively, BRCA2-germline mutant tumors retained the wild-type allele in $16 \%$ of all BRCA2-related ovarian and $46 \%$ of BRCA2 breast tumors. On the other hand, conflicting data for PALB2-BCs has been reported. Most studies have focused on the presence of PALB2 deletions, however, whether the wild-type PALB2 allele may be silenced through the presence of mutations, somatic rearrangements, or epigenetic events is still unknown (Tsuda et al., 1995; Erkko et al., 2007; Tischkowitz et al., 2007; García et al., 2009; Casadei et al., 2011; Hartley et al., 2014). Although the reason for disparities between mice and humans was not elucidated yet, the short lifespan, low rate of $\mathrm{LOH}$ and tissue-specific haploinsufficiency observed in mice may explain these differences (Drost and Jonkers, 2009).

As previously mentioned, haploinsufficiency of BRCA1, BRCA2 and PALB2 genes may be associated to several cellular phenotypes (Buchholz et al., 2002; Lim et al., 2009; Nikkilä et al., 2013). Some data indicate that normal mammary epithelial cells (MEC) from heterozygous for $B R C A$ mutations show increased ability for clonal growth, altered differentiation properties, and aberrant expression profiles (Burga et al., 2009; Lim et al., 2009; Bellacosa et al., 2010; Proia et al., 2011; Feilotter et al., 2014). Moreover, supporting this "haploinsufficiency phenotype", King et al. (2007) identified partial or complete LOH involving the mutant rather than wild-type allele in normal epithelium from $B R C A 1$ and $B R C A 2$ mutation carriers, possibly due to higher susceptibility to mitotic recombination within these cells. In other study, a comprehensive analysis using wild-type $v s$. heterozygous mutant $B R C A 1$ MECs and fibroblasts has provided clues regarding the biological mechanisms of haploinsufficiency (Pathania et al., 2014). They demonstrated that all heterozygous mutant $B R C A 1$ cells exhibited multiple normal $B R C A 1$ functions, including maintenance of homologous recombination-type double-strand break repair, checkpoint functions, centrosome number control and spindle pole formation. However, these cells exhibited innate haploinsufficiency in their ability to support stalled fork repair and prevent replication stress. In contrast, Martins et al. (2012) have identified centrosome abnormalities in the normal breast tissue from $B R C A 1$ mutations carriers. Moreover, Konishi et al. (2011) demonstrated in vitro and in vivo that heterozygous BRCAl mutations confers impaired homology-mediated DNA repair and hypersensitivity to genotoxic stress in MECs. Additional results also revealed higher gene copy number losses and genomic instability in these cells when compared with their respective controls. Taken together, these findings suggest that haploinsufficiency of BRCA1 may accelerate carcinogenesis by facilitating additional genetic alterations. Recently, Savage et al., showed that transcription of the CYPIA gene, which encodes an estrogen-metabolizing enzyme, is upregulated in $B R C A 1$ heterozygous cells. In addition, it was demonstrated that estrogen and estrogen metabolites result in increased DNA DSBs in $B R C A 1$ heterozygous cells. Altogether, these data suggest that BRCA1 haploinsufficiency could result in DNA damage in tissues under estrogen stimulation and provides some clues regarding why breast and ovarian tissues are mostly affected in BRCA mutation carriers (Savage et al., 2014).

In contrast to $B R C A 1$, much less is known about biological mechanisms associated with BRCA2 and PALB2 monoallelic mutations. Arnold et al. (2006) using lymphoblastoid cell lines, have found lower amounts of the fulllength BRCA2 protein in BRCA2 heterozygote cells compared to BRCA2 wild-type. This dosage effect of BRCA2 protein was correlated with an increase in DNA DSBs and an impaired repair of these lesions (Arnold et al., 2006). For some mutations (e.g., truncating mutations) lower amounts of BRCA2 protein also lead to increased chromosomal 
rearrangements and higher rates of sister chromatid exchanges, indicating a higher susceptibility of $B R C A 2$ heterozygous cells to chromosomal abnormalities (Savelyeva et al., 2001; Kim et al., 2004). Defects in the recruitment of RAD51 to DSB sites and in activating HR have also been reported in BRCA2-deficient cells (Yuan et al., 1999). In a study published by Nikkilä et al. (2013), low levels of PALB2 protein, aberrant DNA replication/damage response, as well as elevated chromosome instability was observed in the PALB2 heterozygote state. Moreover, it has been demonstrated that PALB2 mutation increases error-prone DSB repair, but do not affect HR and RAD51 filament assembly. (Obermeier et al., 2015).

In conclusion, heterozygosity for $B R C A 1, B R C A 2$ and $P A L B 2$ mutations may impair different biological mechanisms. Although the impact of these alterations on carcinogenesis remains unknown, these detectable effects of "one hit" potentially represent early molecular changes in tumorigenesis. However, these findings remain inconclusive since most of the studies done so far used small number of samples and non-isogenic cell lines.

\section{Tumor phenotype and genomic landscape of BRCA1, BRCA2 and PALB2-associated tumors}

\section{Histology and immunophenotype}

Invasive ductal carcinoma is the most common histological breast tumor type observed in BRCA1 and BRCA2 carriers (Honrado et al., 2005). Other histological subtypes, including medullary and tubular carcinoma, are also found in this subgroup of patients (Mavaddat et al., 2012). A more detailed examination of morphologic features of the tumors has shown that when compared to sporadic BCs, BRCA1 tumors exhibited higher mitotic counts, more lymphocytic infiltration and greater proportion of the tumor with a continuous pushing margin. On the other hand, BRCA2 tumors are less homogeneous, but exhibit a higher score for tubule formation, higher proportion of the tumor perimeter with a continuous pushing margin, and a lower mitotic count than sporadic BCs (Lakhani et al., 1998). The vast majority of BRCA1 tumors are poorly differential (grade 3), while BRCA2 tumors are usually moderately (grade 2) or poorly (grade 3) differentiated (Agnarsson et al., 1998; Lynch et al., 1998; Palacios et al., 2003). These and other findings have suggested that breast tumors arising in $B R C A 1$ mutation carriers are associated with more aggressive tumor characteristics compared to BRCA2 mutation carriers (Krammer et al., 2017).

Despite being driven by germline mutations in functionally related genes, $B R C A 1, B R C A 2$, and $P A L B 2$ mutated breast cancers constitute a heterogeneous group of tumors at the immunohistochemical and molecular level (Table 1). In a way akin to the morphological findings, at least $70 \%$ of the tumors arising in BRCA1 mutation carriers display a triple-negative phenotype (estrogen receptor (ER)-negative, progesterone receptor (PR)-negative and human epidermal growth factor 2 (HER2)-negative), and are classified as basal-like molecular subtype according to immunohistochemical and microarray data (Sorlie et al., 2003: Badve et al., 2011; Mavaddat et al., 2012). In contrast, BRCA2 tumors have been classified predominantly as hormone receptorpositive (Melchor et al., 2008; Mavaddat et al., 2012). A significant proportion of these tumors are of unclassified subtype, with intermediate characteristics between Luminal A and B subtypes (Melchor et al., 2008). Furthermore, several reports have shown similar prevalence of ER- and PRpositive disease in $B R C A 2$ carriers compared with sporadic controls (Armes et al., 1999; Palacios et al., 2005). Regarding PALB2 tumors, a study conducted by Heikkinen et al. (2009) found that breast tumors arising in patients carrying a Finnish founder mutation in PALB2 (c.1592delT) are more likely to have triple-negative phenotype when compared to non-PALB2 mutation-associated BCs. Additionally, these tumors were more often of higher grade, had greater expression of Ki-67 and were associated to reduced survival (Heikkinen et al., 2009). In most of the cases, however, the clinical phenotype of PALB2-BC resembles that of BRCA2-BC, since both are predominantly ER- and PR-positive (Bane et al., 2007; Tischkowitz et al., 2007; Teo et al., 2013; Antoniou et al., 2014; Cybulski et al., 2015; Nguyen-Dumont et al., 2015). Furthermore, minimal sclerosis was identified as a predictor of germline $P A L B 2$ mutation status, distinguishing $P A L B 2$ mutation carriers from $B R C A 1$ and BRCA2 mutation carriers (Teo et al., 2013).

In addition to a triple-negative phenotype and expression of basal markers, BRCA1 tumors are characterized by high proliferation rate (Foulkes et al., 2003; Lakhani et al., 2005). Overexpression of proteins associated to cell cycle progression (cyclin E, A and B1) as well as low expression of cyclin D1 and cyclin-CDK complex inhibitors such as p16, p27, and p21 has also been observed (Chappuis et al., 2005; Palacios et al., 2005; Honrado et al., 2006). Unlike BRCA1 tumors, BRCA 2 tumors seem to be characterized by higher expression of cell cycle proteins, including cyclin D1, cyclin D3, p27, p16, p21, CDK4, CDK2 and CDK1 (Palacios et al., 2005). A recent study found that BRCA tumors are usually positive for PARP1 (non-cleaved), possibly stimulated by DNA breaks and $B R C A$ deficiency. Lower expression of RAD51 and BARD1, two key components of DNA damage repair by HR, were also found in BRCA1 and BRCA1/BRCA2 tumors, respectively, when compared with sporadic BCs (Aleskandarany et al., 2015). PALB2 BCs are not different from other breast tumors regarding cytokeratin 5/6 and 17 expression, but show higher expression of Ki-67 and lower cyclin D1 than other familial and sporadic BCs (Heikkinen et al., 2009).

\section{Link between BRCA1 and ER status}

Despite the evident association between BRCA1 tumors and a triple-negative phenotype, the complete mechanisms underlying this correlation are still unclear. Findings of in vitro studies have suggested that BRCA1 directly modulates ER expression in $\mathrm{BC}$, and that BRCA1 deficiency 
Table 1 - Pathological and molecular characteristics of $B R C A 1, B R C A 2$ and $P A L B 2$-associated breast tumors.

\begin{tabular}{|c|c|c|c|c|}
\hline & BRCA1 tumors & BRCA2 tumors & PALB2 tumors & References \\
\hline \multicolumn{5}{|l|}{ Immunophenotype } \\
\hline \multirow[t]{2}{*}{ ER-positive } & $22 \%$ & $77 \%$ & $53 \%$ & Mavaddat et al., 2012 \\
\hline & & & & Heikkinen et al., 2009 \\
\hline \multirow[t]{2}{*}{ PR-positive } & $21 \%$ & $64 \%$ & $43 \%$ & Mavaddat et al., 2012 \\
\hline & & & & Heikkinen et al., 2009 \\
\hline \multirow[t]{2}{*}{ HER2-positive } & $10 \%$ & $13 \%$ & $4 \%$ & Mavaddat et al., 2012 \\
\hline & & & & Heikkinen et al., 2009 \\
\hline \multirow[t]{2}{*}{ Cyclin D1 } & Usually negative & Usually positive & Usually negative/Low & Palacios et al., 2005, Heikkinen et al., 2009 \\
\hline & & & & Armes et al., 1999 \\
\hline Cyclins E, A and B1 & Usually positive & Usually negative & - & Palacios et al., 2005 \\
\hline $\mathrm{p} 16, \mathrm{p} 27$ and $\mathrm{p} 21$ & Usually negative & Usually positive & - & Palacios et al., 2005 \\
\hline \multirow[t]{2}{*}{ PTEN loss } & $>80 \%$ & - & - & Phuah et al., 2012 \\
\hline & & & & Saal et al., 2008 \\
\hline Basal markers & Usually positive & Usually negative & Usually negative & $\begin{array}{l}\text { Honrado et al., 2006, Heikkinen et al., } 2009 \\
\text { Armes et al., } 1999\end{array}$ \\
\hline $\mathrm{Ki}-67$ & Higher expression $^{\mathrm{a}}$ & Similara & Higher expressiona & Heikkinen et al., 2009 \\
\hline \multicolumn{5}{|l|}{ Genetic alterations } \\
\hline TP53 somatic mutation ${ }^{\mathrm{b}}$ & $67-95 \%$ & $66 \%$ & - & Manié et al., 2009; Crook et al., 1998 \\
\hline$B R C A$ or $P A L B 2 \mathrm{LOH}$ & $84-100 \%$ & $54-83 \%$ & $0-33 \%$ & $\begin{array}{l}\text { Martins et al., 2012; Tung et al., 2010; } \\
\text { Osorio et al., 2002; Hartley, 2014; } \\
\text { Tischkowitz et al., 2007; Maxwell et } \\
\text { al., } 2017 .\end{array}$ \\
\hline$M Y C$ amplification & $18-53 \%$ & $62 \%$ & & Network, 2012; Palacios et al., 2003 \\
\hline$C C N D 1$ amplification & $0-22 \%$ & $13-60 \%$ & & $\begin{array}{l}\text { Vaziri et al., 2001; Plevova et al., 2010; } \\
\text { Brown et al., 2010; }\end{array}$ \\
\hline
\end{tabular}

would result in an ER-negative phenotype (Hosey et al., 2007; Gorski et al., 2009;). Furthermore, there is evidence showing that the differentiation status of breast stem cells may be regulated by BRCA1 and that these breast tumors originate from ER-negative luminal progenitor cells (Lim et al., 2009; Molyneux et al., 2010). However, at least 20\% of all breast tumors arising in the $B R C A 1$ germline mutation carriers express ER (Mavaddat et al., 2012). Some authors argue that these cancers are not linked to $B R C A 1$ germline mutations, but most likely constitute sporadic ER-positive tumors (Tung et al., 2010). In contrast, Natrajan et al. (2012) using whole genome massively parallel sequencing, showed that ER-positive and ER-negative $B R C A 1$ cancers share a very similar genomic landscape, therefore suggesting that at least a subset of ER-positive BRCA1 mutant tumors are not sporadic, but associated with BRCA1 deficiency. In agreement, there are data suggesting that the prevalence of loss of wild-type BRCA1 between ER+ and ER- invasive BRCA1 breast tumors does not differ (Natrajan et al., 2012). Moreover, it seems that absence of $B R C A 1$ is not sufficient for breast tumors to harbor an ER-negative phenotype (Joosse, 2012).

\section{Genomic alterations}

Initial whole-exome sequencing analyses of BRCAassociated breast and ovarian cancers have demonstrated, in a small number of tumors, that at base pair resolution the repertoire of somatic mutations that these cancers harbor is diverse (Figure 1) (Network, 2011, 2012). The most frequently mutated gene in both BRCA1 and BRCA2 tumors (breast and ovarian) is TP53. In addition, analysis of copy number alterations (CNAs) revealed that approximately $30 \%$ of these tumors harbored recurrent amplifications of $M Y C$ and TERC. For PALB2-BCs, the repertoire of somatic mutations is currently unknown.

A noteworthy genetic alteration observed in BRCAassociated tumors is the high frequency of somatic mutations affecting TP53 (Crook et al., 1997; Network 2011, 2012). The $\mathrm{p} 53$ protein, encoded by the TP53 gene, is a potent transcription factor involved in many tumor suppressing mechanisms, such as cell cycle arrest, DNA repair, senescence and apoptosis (Vousden and Prives, 2009). Somatic TP53 mutations have been reported in more than $60 \%$ of BRCA1-BCs but in lower frequency in BRCA2 breast tumors (Crook et al., 1998; Manié et al., 2009; Network, 2012). Interestingly, a significant proportion of TP53 somatic mutations are protein-truncating (nonsense and frameshift mutations), suggesting strong selection for p53 loss-of-function rather than 


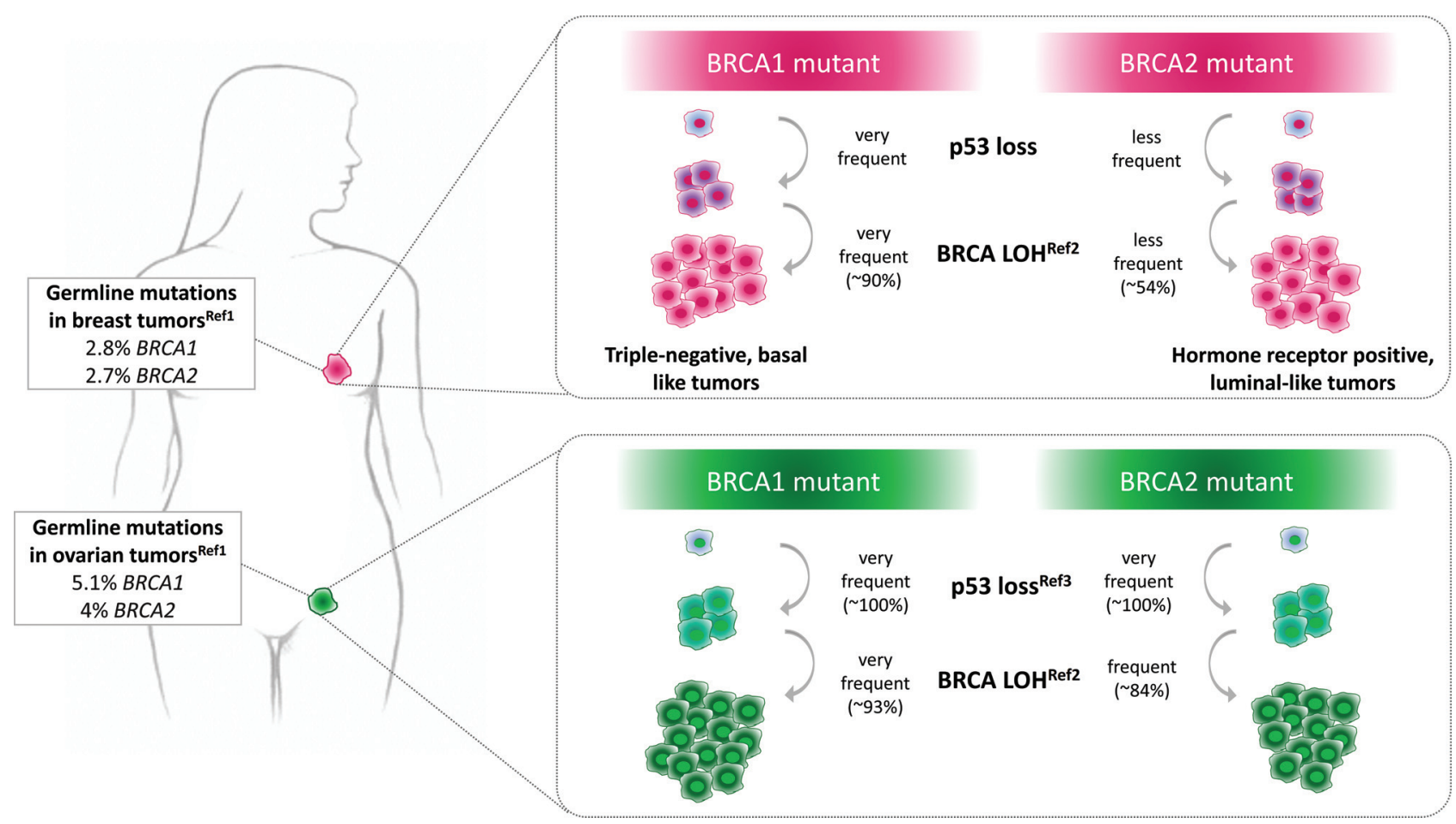

Figure 1 - Frequent alterations arising in breast and ovarian tumors from patients carrying germline mutations in $B R C A 1$ and $B R C A 2$. For details, see Ref 1 (Kurian et al., 2017), Ref 2 (Maxwell et al., 2017) and Ref3 (Network, 2011).

missense hotspot mutations (Holstege et al., 2009). Also, a high prevalence of TP53 mutations has also been observed in BRCA-associated ovarian cancers (Network 2011). In fact, the contribution of $\mathrm{p} 53$ to tumorigenesis of Brca tumors has been demonstrated in mouse models. $\mathrm{BrCaI}^{+/} \mathrm{Trp} 53^{+/}$and $\mathrm{BrCa}^{+/}{ }^{-} \mathrm{Trp} 53^{+/-}$mice show a slight increase in mammary carcinoma incidence compared with $\operatorname{Trp} 53^{+/-}$mice (Cressman et al., 1999; Jonkers et al., 2001). As shown recently, in BCs, TP53 mutations seem to be the second most common first event (after PTEN loss and BRCA1 wild-type LOH) (Martins et al., 2012). In ovarian cancer, TP53 mutations seems to be a prerequisite to $B R C A 1$-associated carcinogenesis, occurring before loss of the wild-type allele (Norquist et al., 2010).

In addition to TP53, PTEN (phosphatase and tensin homolog) has also been shown to contribute to carcinogenesis of BRCA1-associated BC (Martins et al., 2012). The protein product of PTEN is a potent inhibitor of the phosphatidylinositol 3-Kinase (PI3K) pathway, an oncogenic signaling cascade that promotes many of the cancer hallmarks (Carracedo and Pandolfi, 2008). Findings of in vivo studies have shown that mice carrying heterozygous inactivation of PTEN develop basal-like mammary tumors (Saal et al., 2008). Additionally, in breast tumors arising in BRCA1 mutations carriers, PTEN loss has been detected in more than $80 \%$ of the cases (Saal et al., 2008; Phuah et al., 2012). The inactivation of PTEN seems to contribute to the high rate of gene rearrangements involving DNA DSBs, intragenic inversions, insertions, and homozygous deletions found in BRCA1 tumors (Saal et al., 2008). Moreover, in
BRCA1 breast tumors, loss of PTEN has been show to precede BRCAl LOH and TP53 mutation (Martins et al., 2012). Interestingly, PTEN deficiency may also result in increased chromosomal instability due to its role in controlling the expression of RAD51 and cell cycle checkpoint (Shen et al., 2007; Gupta et al., 2009).

As mentioned previously, a common genetic alteration of BRCA1 and BRCA2 tumors is LOH. Although different studies have shown that most of BRCA tumors share this feature, findings demonstrating that $B R C A$ wild-type allele may be preserved in a subset of cancer cells and that some BRCA tumors may not display loss of $B R C A$ wild-type allele at all have raised issues regarding the true impact of the $B R C A \mathrm{LOH}$ on tumorigenesis (Osorio et al., 2002; Tung et al., 2010; Stefansson et al., 2011; Martins et al., 2012; Maxwell et al., 2017). Several studies have found that in a substantial proportion of the cases, loss of the BRCA wildtype allele is not an initial event (Stefansson et al., 2011; Martins et al., 2012;). The findings obtained by Stefansson et al. (2011) support the hypothesis that loss of the BRCA2 wild-type allele is a late, rather than early, event in progression of the disease. King et al. (2007) have suggested that $\mathrm{LOH}$ is not required for the tumorigenesis of BRCA breast tumors, since a high level of heterogeneity to this molecular event within and between pre-invasive lesions and invasive cancers was found. For PALB2-related BCs, the few reports to date have found controversial results regarding $\mathrm{LOH}$ of PALB2 (Tischkowitz et al., 2007; Hartley et al., 2014).

It has also been found that BRCA-related tumors are characterized by a distinct mutational signature (signature 
3), in which large deletions with overlapping microhomology at breakpoint junctions are found, likely associated with absence of BRCA1 or BRCA2 functions (Alexandrov et al., 2013; Nik-Zainal et al., 2016). Recently, it was demonstrated that, in contrast to tumors with biallelic germline inactivation of BRCA, single functional copies of BRCA (generally sufficient to maintain normal HR function) were not associated with signature 3 (Polak et al., 2017).

With regard to CNAs, BRCA1 and BRCA2 breast tumors show different patterns of gains and losses compared to sporadic tumors (Jönsson et al., 2005), and despite overlaps between BRCA1 and BRCA2 tumors many differences have been observed at this genomic level (van der Groep et al., 2011). For PALB2 breast tumors, 1q gain, 20q gain, and 18q loss were consistently observed across tumors (Tischkowitz et al., 2007). In BRCA-related epithelial ovarian carcinomas the few number of studies have yielded contradictory results. Despite the fact that some data indicate that somatic alterations do not differ substantially from the ones occurring in sporadic carcinomas (Kamieniak et al., 2013), several reports have shown that BRCA ovarian cancers exhibit a significantly higher number of chromosomal aberrations and genomic imbalances than sporadic tumors (Israeli et al., 2003; Walsh et al., 2008).

\section{New therapeutic approaches}

\section{Targeting homologous recombination deficiency}

Many of the therapies newly developed for patients with $B R C A 1$ and BRCA2-mutated BCs explore the fact that these tumors lack DSB DNA repair by HR (Livraghi and Garber, 2015). The most promising therapies within this category are the inhibitors of poly (ADP-ribose) polymerase (PARP) (Evans and Matulonis, 2017). The discovery of the synthetic lethality interactions between PARP inhibitors and HR repair deficiency provided the basis for the clinical approval of olaparib in ovarian cancer and ongoing clinical trials of other drugs.

The PARPs are a large family of enzymes, which, in addition to other functions, participate in single-strand breaks (SSBs) repair via the base-excision repair (BER) pathway (Ashworth, 2008). Despite the importance of their

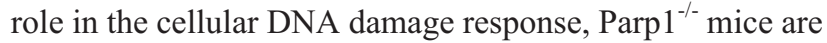
viable, fertile and do not develop early onset tumors (Wang et al., 1995; Conde et al., 2001). However, the inability of Parp $1^{-1 /}$ cells repairing SSBs via PARP activity lead to stalling and collapse of replication forks in proliferation cells, transforming SSBs in DSBs, which may potentially be repaired by HR (Peng and Lin, 2011).

In 2005, two simultaneous publications demonstrated the impact of PARP inhibition in BRCA1 and BRCA2deficient cells. The results of both studies showed that the complete dysfunction of BRCA proteins linked to PARP1 inhibition lead to chromosomal instability, cell cycle arrest, and apoptosis (Bryant et al., 2005; Farmer et al., 2005). These findings illustrate the concept of 'synthetic lethality', a phenomenon that occurs when the combination of two dif- ferent mutations or cellular pathways inhibition lead to cell death, whereas one of the two events alone does not (Lord and Ashworth, 2017)

After in vitro and in vivo studies proved the synthetic lethality between PARP1 inhibition and BRCA dysfunction, an obvious next step was the validation of this paradigm in a clinical setting. Since then, several clinical trials have been launched to test the activity of different PARP inhibitors in the patient's population carrying $B R C A$ germline mutations. Several PARP inhibitors, including olaparib, niraparib, rucaparib, and BMN-673 are in different clinical phases of testing and have shown promising therapeutic activity such as in monotherapy (Fong et al., 2009; Drew et al., 2016; de Bono et al., 2017).

The first-in-human phase I study of olaparib (also known as AZD2281) found antitumor activity in breast and ovarian tumors arising in $B R C A$ carriers, but not in patients without such mutations. In addition, minimal toxic effects, which are commonly associated with conventional chemotherapy, were observed. (Fong et al., 2009). Subsequently, a phase II proof-of-concept trial provided evidences for the efficacy and tolerability of olaparib therapy in women carrying $B R C A$ mutation and advanced-stage breast cancer (Tutt et al., 2010). Similar results were obtained in an independent study including women with confirmed $B R C A$ germline mutations and ovarian cancer (Audeh et al., 2010). In 2015 a multicenter open-label phase II study including 298 BRCA mutation carriers which were refractory to standard therapy showed clinical benefit of olaparib in prostate and pancreatic cancer and confirmed activity in ovarian and breast cancer (Kaufman et al., 2015). In 2014, olaparib was the first PARP inhibitor to receive regulatory approval in the United States and Europe to treat recurrent ovarian cancers associated to $B R C A$ mutations as maintenance therapy postplatinum treatment. The accelerated approval was based on the results of the phase III SOLO2 study (Pujade-Lauraine et al., 2017).

Initially found to induce synthetic lethality in preclinical model of BRCA loss-of-function (Jones et al., 2009a), the first phase I study of niraparib (MK-4827), a highly selective inhibitor of PARP1 and PARP2, showed antitumor activity and a low frequency of high-grade toxic effects (Sandhu et al., 2013). Subsequently, in a randomized, placebo-controlled, phase III trial it was demonstrated the efficacy and safety of niraparib as maintenance treatment in a broad population of patients with platinum-sensitive, recurrent ovarian cancer, regardless of the presence or absence of BRCA1, BRCA2 mutations or HR deficiency status (Mirza et al., 2016). This study was the basis for approval of the drug by the United States' FDA in October 2016.

Talazoparib, another compound belonging to the PARP inhibitors class, initially showed encouraging clinical results. First tested in vitro, the drug selectively targeted tumor cells with $B R C A 1, B R C A 2$, or PTEN gene alterations with 20- to more than 200-fold greater potency than existing PARP1/2 inhibitors (such as olaparib, rucaparib, and veliparib) (Shen et al., 2013). Preclinical results demonstrated that the potency in trapping PARP differed markedly among 
PARP inhibitors, a pattern not correlated with the catalytic inhibitory properties for each drug. However, preclinical potency may not necessarily translate into clinical efficacy, as other factors such as drug-related toxicities limiting dose escalation and patient selection come into play (Brown et al., 2016).

In a pre-clinical study, rucaparib was found to be cytotoxic to $B R C A$ mutated cells and associated with a reduction in growth of xenograft tumors harboring $B R C A$ mutations (Drew et al., 2011). In a phase II trial with BRCAovarian cancers, rucaparib was well tolerated and associated with stable disease (Drew et al., 2016). Rucaparib was tested in two main clinical trials, ARIEL2 and ARIEL3. Data showed progression-free survival advantage for patients with BRCA mutant platinum-sensitive ovarian carcinomas. The drug was recently approved by the FDA (Swisher et al., 2017).

Over the past decade a new concept termed 'BRCAness' has been proposed. BRCAness was described as a phenomenon in which HR deficiency occurs in a tumor not due to a $B R C A 1$ or $B R C A 2$ germline mutation, but by mutations in other genes involved in HR (Lord and Ashworth, 2016). The experience with PARP inhibitors demonstrates that the use of this therapeutic approach may be expanded, including to other tumors with HR deficiency, regardless of tumor site (Riaz et al., 2017). However, the clinical utility of this approach requires further validation (Frey and Pothuri, 2017).

More recently, some authors have suggested that patients with $B R C A 1$ or $B R C A 2$ germline mutations harbour a greater number of clonal mutations compared with $B R C A$ wild-type tumors (Nik-Zainal et al., 2012). This can lead to a more pronounced immunogenic phenotype and better response to immune checkpoint inhibitors (Dai et al., 2018).

\section{Resistance mechanisms}

Although PARP inhibitors have emerged as promising new therapeutic approaches for tumors arising in $B R C A$ mutation carriers, drug resistance has become an important clinical issue. The investigation of the multiple potential resistance mechanisms has led to the identification of both processing operating through the drug target and under $B R C A 1, B R C A 2$, and their pathways (Lord and Ashworth, 2013).

Discovered independently by two groups, secondary mutation is the most common mechanism of acquired resistance to PARP inhibitors. Edwards et al. (2008) using the CAPAN1 pancreatic cancer cell line which harbors a $B R C A 2$ frameshift mutation (c.6174delT), found that resistant clones to PARP inhibitors could form RAD51 nuclear foci and prevent genomic instability, both of which are hallmarks of an efficient HR. These resistant clones displayed a secondary $B R C A 2$ intragenic deletion of the region containing c.6174delT mutation and restoration of the open reading frame (ORF), resulting in the expression of new BRCA2 isoforms (Edwards et al., 2008). Similar results were also observed in cisplatin-resistant BRCA2-mutated breast-cancer cell line (Sakai et al., 2008). In ovarian cancers, secondary mutations restoring the BRCA2 ORF were also observed in patients who become resistant to platinum salts (Edwards et al., 2008; Sakai et al., 2008). Barber et al. (2013) analyzed resistance to olaparib in a male patient with $\mathrm{BC}$ and a woman with breast and ovarian cancer that were enrolled in a phase II clinical trial. Both were carriers of a truncating BRCA2 mutation and presented multiple metastatic lesions. Deep sequencing of treatment-naive and olaparib-resistant lesions from both patients indicated the emergence of secondary mutations that potentially restored de ORF of BRCA2 gene only in the resistant lesions (Barber et al., 2013). Taken together, these data provide evidence that, at least in a subset of patients, platinum salts and PARP inhibitors require defective HR for their antitumor activity. Although the frequency of secondary $B R C A$ mutations is not precisely known, this is the most well validated mechanism of resistance to PARP inhibitors in the population of patients carrying $B R C A$ mutations.

Reduced activity of p53 binding protein 1 (53BP1) has also been suggested as a potential resistance mechanism to PARP inhibitors (Lord and Ashworth, 2013). Initial studies have showed that mouse embryonic fibroblasts without a full-length form of BRCA1 and deleted 53bp 1 are defective in induction of senescence and cell death. Furthermore, in vivo results confirmed that the embryonic lethality associated with complete BRCA1-deficiency may be alleviated by 53 bp1 deletion (Cao et al., 2009). Bouwman et al. (2010) showed that loss of 53BP1 partially restores the HR defect of BRCA1-deficient cells and reverts their hypersensitivity to DNA-damaging agents. Moreover, these findings have potential clinical implications, given that reduced 53BP1 expression was found in a subset of sporadic triple-negative and BRCA-associated BCs (Bouwman et al., 2010). Further study in a mouse model of Brcal deficiency showed that mammary gland tumors that initially were sensitive to olaparib developed resistance associated with 53bp1 factor. In a subset of the cases ( 3 out of 11), this resistance was caused by partial restoration of HR due to somatic loss of 53BP1 (Jaspers et al., 2013). On the other hand, 53bp1 depletion did not have any effect on cells with BRCA2 deficiency.

\section{Conclusion and perspectives}

After two decades of efforts, we have witnessed remarkable advances in our understanding of basic aspects of $B R C A$ and $P A L B 2$ genes. The roles of these genes in DNA repair by $\mathrm{HR}$ and the discovery of synthetic lethal interaction between PARP inhibition and BRCA1 or BRCA2 deficiency allowed us to make significant progress in the clinical setting. However, many questions remain. For example, although the identification of abnormal phenotypes has been described even in normal cells of BRCA and PALB2 germline mutation carriers, suggesting haploinsufficiency for specific BRCA functions, the contribution of this finding 
to cancer predisposition still remains controversial. Additionally, the molecular basis underlying the tissue-specificity of cancer predisposition associated with germline $B R C A$ and PALB2 mutations as well as the impact of the $B R C A$ or $P A L B 2$ wild-type allele (absence of $\mathrm{LOH}$ ) within tumors on the DNA repair by HR and response to therapies requires further evaluation. Finally, our complete understanding of the molecular abnormalities in BRCA and PALB2-associated tumors will not only provide insights into the pathogenesis of these cancers, but also will help to identify novel targets for therapies as well as predictive markers for HR deficiency and drug response.

\section{Conflict of interest}

The authors have no conflicts of interest to declare.

\section{Author contributions}

All three authors contributed to the writing of the manuscript and approved its final version.

\section{References}

Agnarsson BA, Jonasson JG, Björnsdottir IB, Barkardottir RB, Egilsson V and Sigurdsson H (1998) Inherited BRCA2 mutation associated with high grade breast cancer. Breast Cancer Res Treat 47:121-127.

Al-Mulla F, Bland JM, Serratt D, Miller J, Chu C and Taylor GT (2009) Age-dependent penetrance of different germline mutations in the BRCA1 gene. J Clin Pathol 62:350-356.

Alemar B, Gregório C, Herzog J, Matzenbacher Bittar C, Brinckmann Oliveira Netto C, Artigalas O, D Schwartz IV, Coffa J, Alves Camey S, Weitzel J et al. (2017) BRCA1 and BRCA2 mutational profile and prevalence in hereditary breast and ovarian cancer (HBOC) probands from Southern Brazil: Are international testing criteria appropriate for this specific population? PLoS One 12:e0187630.

Aleskandarany M, Caracappa D, Nolan CC, Macmillan RD, Ellis IO, Rakha EA and Green AR (2015) DNA damage response markers are differentially expressed in BRCA-mutated breast cancers. Breast Cancer Res Treat 150:81-90.

Alexandrov LB, Nik-Zainal S, Wedge DC, Aparicio SA, Behjati S, Biankin AV, Bignell GR, Bolli N, Borg A, Børresen-Dale AL et al. (2013) Signatures of mutational processes in human cancer. Nature 500:415-421.

Alter BP, Rosenberg PS and Brody LC (2007) Clinical and molecular features associated with biallelic mutations in FANCD1/BRCA2. J Med Genet 44:1-9.

Anderson DE and Badzioch MD (1992) Breast cancer risks in relatives of male breast cancer patients. J Natl Cancer Inst 84:1114-1117.

Antoniou A, Pharoah PD, Narod S, Risch HA, Eyfjord JE, Hopper JL, Loman N, Olsson H, Johannsson O, Borg A et al. (2003) Average risks of breast and ovarian cancer associated with BRCA1 or BRCA2 mutations detected in case Series unselected for family history: a combined analysis of 22 studies. Am J Hum Genet 72:1117-1130.

Antoniou AC, Casadei S, Heikkinen T, Barrowdale D, Pylkäs K, Roberts J, Lee A, Subramanian D, De Leeneer K, Fostira F et al. (2014) Breast-cancer risk in families with mutations in PALB2. N Engl J Med 371:497-506.
Armes JE, Trute L, White D, Southey MC, Hammet F, Tesoriero A, Hutchins AM, Dite GS, McCredie MR, Giles GG et al. (1999) Distinct molecular pathogeneses of early-onset breast cancers in BRCA1 and BRCA2 mutation carriers: a population-based study. Cancer Res 59:2011-2017.

Arnold K, Kim MK, Frerk K, Edler L, Savelyeva L, Schmezer P and Wiedemeyer R (2006) Lower level of BRCA2 protein in heterozygous mutation carriers is correlated with an increase in DNA double strand breaks and an impaired DSB repair. Cancer Lett 243:90-100.

Ashworth A (2008) A synthetic lethal therapeutic approach: poly(ADP) ribose polymerase inhibitors for the treatment of cancers deficient in DNA double-strand break repair. J Clin Oncol 26:3785-3790.

Ashworth A, Lord CJ and Reis-Filho JS (2011) Genetic interactions in cancer progression and treatment. Cell 145:30-38.

Audeh MW, Carmichael J, Penson RT, Friedlander M, Powell B, Bell-McGuinn KM, Scott C, Weitzel JN, Oaknin A, Loman N et al. (2010) Oral poly(ADP-ribose) polymerase inhibitor olaparib in patients with BRCA1 or BRCA2 mutations and recurrent ovarian cancer: a proof-of-concept trial. Lancet 376:245-251.

Badie S, Escandell JM, Bouwman P, Carlos AR, Thanasoula M, Gallardo MM, Suram A, Jaco I, Benitez J, Herbig U et al. (2010) BRCA2 acts as a RAD51 loader to facilitate telomere replication and capping. Nat Struct Mol Biol 17:1461-1469.

Badve S, Dabbs DJ, Schnitt SJ, Baehner FL, Decker T, Eusebi V, Fox SB, Ichihara S, Jacquemier J, Lakhani SR et al. (2011) Basal-like and triple-negative breast cancers: a critical review with an emphasis on the implications for pathologists and oncologists. Mod Pathol 24:157-167.

Baldeyron C, Jacquemin E, Smith J, Jacquemont C, De Oliveira I, Gad S, Feunteun J, Stoppa-Lyonnet D and Papadopoulo D (2002) A single mutated BRCA1 allele leads to impaired fidelity of double strand break end-joining. Oncogene 21:1401-1410.

Bane AL, Beck JC, Bleiweiss I, Buys SS, Catalano E, Daly MB, Giles G, Godwin AK, Hibshoosh H, Hopper JL et al. (2007) BRCA2 mutation-associated breast cancers exhibit a distinguishing phenotype based on morphology and molecular profiles from tissue microarrays. Am J Surg Pathol 31:121-128.

Barber LJ, Sandhu S, Chen L, Campbell J, Kozarewa I, Fenwick K, Assiotis I, Rodrigues DN, Reis Filho JS, Moreno V et al. (2013) Secondary mutations in BRCA2 associated with clinical resistance to a PARP inhibitor. J Pathol 229:422-429.

Basham VM, Lipscombe JM, Ward JM, Gayther SA, Ponder BA, Easton DF and Pharoah PD (2002) BRCA1 and BRCA2 mutations in a population-based study of male breast cancer. Breast Cancer Res 4:R2.

Bellacosa A, Godwin AK, Peri S, Devarajan K, Caretti E, Vanderveer L, Bove B, Slater C, Zhou Y, Daly M et al. (2010) Altered gene expression in morphologically normal epithelial cells from heterozygous carriers of BRCA1 or BRCA2 mutations. Cancer Prev Res 3:48-61.

Berger AH, Knudson AG and Pandolfi PP (2011) A continuum model for tumour suppression. Nature 476:163-169.

Borg A, Haile RW, Malone KE, Capanu M, Diep A, Törngren T, Teraoka S, Begg CB, Thomas DC, Concannon P et al. (2010) Characterization of BRCA1 and BRCA2 deleterious mutations and variants of unknown clinical significance in unilateral and bilateral breast cancer: the WECARE study. Hum Mutat 31:E1200-1240.

Bouwman P, Aly A, Escandell JM, Pieterse M, Bartkova J, van der Gulden H, Hiddingh S, Thanasoula M, Kulkarni A, Yang Q et 
al. (2010) 53BP1 loss rescues BRCA1 deficiency and is associated with triple-negative and BRCA-mutated breast cancers. Nat Struct Mol Biol 17:688-695.

Bowman-Colin C, Xia B, Bunting S, Klijn C, Drost R, Bouwman P, Fineman L, Chen X, Culhane AC, Cai H et al. (2013) Palb2 synergizes with Trp53 to suppress mammary tumor formation in a model of inherited breast cancer. Proc Natl Acad Sci U S A 110:8632-8637.

Brandsma I and Gent DC (2012) Pathway choice in DNA double strand break repair: observations of a balancing act. Genome Integr 3:9.

Brose MS, Rebbeck TR, Calzone KA, Stopfer JE, Nathanson KL and Weber BL (2002) Cancer risk estimates for BRCA1 mutation carriers identified in a risk evaluation program. J Natl Cancer Inst 94:1365-1372.

Brown LA, Johnson K, Leung S, Bismar TA, Benítez J, Foulkes WD and Huntsman DG (2010) Co-amplification of CCND1 and EMSY is associated with an adverse outcome in ERpositive tamoxifen-treated breast cancers. Breast Cancer Res Treat 121:347-54

Brown JS, Kaye SB and Yap TA (2016) PARP inhibitors: the race is on. Br J Cancer 114:713-715.

Bryant HE, Schultz N, Thomas HD, Parker KM, Flower D, Lopez E, Kyle S, Meuth M, Curtin NJ and Helleday T (2005) Specific killing of BRCA2-deficient tumours with inhibitors of poly(ADP-ribose) polymerase. Nature 434:913-917.

Buchholz TA, Wu X, Hussain A, Tucker SL, Mills GB, Haffty B, Bergh S, Story M, Geara FB and Brock WA (2002) Evidence of haplotype insufficiency in human cells containing a germline mutation in BRCA1 or BRCA2. Int J Cancer 97:557-561.

Burga LN, Tung NM, Troyan SL, Bostina M, Konstantinopoulos PA, Fountzilas H, Spentzos D, Miron A, Yassin YA, Lee BT et al. (2009) Altered proliferation and differentiation properties of primary mammary epithelial cells from BRCA1 mutation carriers. Cancer Res 69:1273-1278.

Burma S, Chen BP and Chen DJ (2006) Role of non-homologous end joining (NHEJ) in maintaining genomic integrity. DNA Repair 5:1042-1048.

Buys SS, Sandbach JF, Gammon A, Patel G, Kidd J, Brown KL, Sharma L, Saam J, Lancaster J and Daly MB (2017) A study of over 35,000 women with breast cancer tested with a 25gene panel of hereditary cancer genes. Cancer 123:17211730.

Cao L, Xu X, Bunting SF, Liu J, Wang RH, Cao LL, Wu JJ, Peng TN, Chen J, Nussenzweig A et al. (2009) A selective requirement for 53BP1 in the biological response to genomic instability induced by Brcal deficiency. Mol Cell 35:534-541.

Carracedo A and Pandolfi PP (2008) The PTEN-PI3K pathway: of feedbacks and cross-talks. Oncogene 27:5527-5541.

Casadei S, Norquist BM, Walsh T, Stray S, Mandell JB, Lee MK, Stamatoyannopoulos JA and King MC (2011) Contribution of inherited mutations in the BRCA2-interacting protein PALB2 to familial breast cancer. Cancer Res 71:2222-2229.

Chappuis PO, Donato E, Goffin JR, Wong N, Bégin LR, Kapusta LR, Brunet JS, Porter P and Foulkes WD (2005) Cyclin E expression in breast cancer: predicting germline BRCA1 mutations, prognosis and response to treatment. Ann Oncol 16:735-742.

Cheon JY, Mozersky J and Cook-Deegan R (2014) Variants of uncertain significance in BRCA: a harbinger of ethical and policy issues to come? Genome Med 6:121.

Choi E, Park PG, Lee HO, Lee YK, Kang GH, Lee JW, Han W, Lee HC, Noh DY, Lekomtsev S et al. (2012) BRCA2 fine-tunes the spindle assembly checkpoint through reinforcement of BubR1 acetylation. Dev Cell 22:295-308.

Conde C, Mark M, Oliver FJ, Huber A, de Murcia G and Ménissier-de Murcia J (2001) Loss of poly(ADP-ribose) polymerase- 1 causes increased tumour latency in $\mathrm{p} 53$-deficient mice. EMBO J 20:3535-3543.

Connor F, Smith A, Wooster R, Stratton M, Dixon A, Campbell E, Tait TM, Freeman T and Ashworth A (1997) Cloning, chromosomal mapping and expression pattern of the mouse Brca2 gene. Hum Mol Genet 6:291-300.

Consortium BCL (1999) Cancer risks in BRCA2 mutation carriers. J Natl Cancer Inst 91:1310-1316.

Couch FJ, Shimelis H, Hu C, Hart SN, Polley EC, Na J, Hallberg E, Moore R, Thomas A, Lilyquist J et al. (2017) Associations between cancer predisposition testing panel genes and breast cancer. JAMA Oncol 3:1190-1196.

Cressman VL, Backlund DC, Hicks EM, Gowen LC, Godfrey V and Koller BH (1999) Mammary tumor formation in p53- and BRCA1-deficient mice. Cell Growth Differ 10:1-10.

Crook T, Crossland S, Crompton MR, Osin P and Gusterson BA (1997) p53 mutations in BRCA1-associated familial breast cancer. Lancet 350:638-639.

Crook T, Brooks LA, Crossland S, Osin P, Barker KT, Waller J, Philp E, Smith PD, Yulug I, Peto J et al. (1998) p53 mutation with frequent novel condons but not a mutator phenotype in BRCA1- and BRCA2-associated breast tumours. Oncogene 17:1681-1689.

Csokay B, Udvarhelyi N, Sulyok Z, Besznyak I, Ramus S, Ponder B and Olah E (1999) High frequency of germ-line BRCA2 mutations among Hungarian male breast cancer patients without family history. Cancer Res 59:995-998.

Cybulski C, Kluzniak W, Huzarski T, Wokolorczyk D, Kashyap A, Jakubowska A, Szwiec M, Byrski T, Debniak T, Górski B et al. (2015) Clinical outcomes in women with breast cancer and a PALB2 mutation: A prospective cohort analysis. Lancet Oncol 16:638-644.

Dai Y, Sun C, Feng Y, Jia Q and Zhu B (2018) Potent immunogenicity in BRCA1-mutated patients with high-grade serous ovarian carcinoma. J Cell Mol Med 22:3979-3986.

de Bono J, Ramanathan RK, Mina L, Chugh R, Glaspy J, Rafii S, Kaye S, Sachdev J, Heymach J, Smith DC et al. (2017) Phase I, dose-escalation, two-part trial of the PARP inhibitor talazoparib in patients with advanced germline BRCA1/2 mutations and selected sporadic cancers. Cancer Discov 7:620629.

Ding YC, Steele L, Kuan CJ, Greilac S and Neuhausen SL (2011) Mutations in BRCA2 and PALB2 in male breast cancer cases from the United States. Breast Cancer Res Treat 126:771-778.

Drew Y, Mulligan EA, Vong WT, Thomas HD, Kahn S, Kyle S, Mukhopadhyay A, Los G, Hostomsky Z, Plummer ER et al. (2011) Therapeutic potential of poly(ADP-ribose) polymerase inhibitor AG014699 in human cancers with mutated or methylated BRCA1 or BRCA2. J Natl Cancer Inst 103:334346.

Drew Y, Ledermann J, Hall G, Rea D, Glasspool R, Highley M, Jayson G, Sludden J, Murray J, Jamieson D et al. (2016) Phase 2 multicentre trial investigating intermittent and continuous dosing schedules of the poly(ADP-ribose) polymerase inhibitor rucaparib in germline BRCA mutation carriers with advanced ovarian and breast cancer. $\mathrm{Br} \mathrm{J}$ Cancer 114:723-730.

Drost RM and Jonkers J (2009) Preclinical mouse models for BRCA1-associated breast cancer. Br J Cancer 101:16511657. 
Edwards SL, Brough R, Lord CJ, Natrajan R, Vatcheva R, Levine DA, Boyd J, Reis-Filho JS and Ashworth A (2008) Resistance to therapy caused by intragenic deletion in BRCA2. Nature 451:1111-1115.

Eliade M, Skrzypski J, Baurand A, Jacquot C, Bertolone G, Loustalot C, Coutant C, Guy F, Fumoleau P, Duffourd Y et al. (2017) The transfer of multigene panel testing for hereditary breast and ovarian cancer to healthcare: What are the implications for the management of patients and families? Oncotarget 8:1957-1971.

Erkko H, Xia B, Nikkilä J, Schleutker J, Syrjäkoski K, Mannermaa A, Kallioniemi A, Pylkäs K, Karppinen SM, Rapakko K et al. (2007) A recurrent mutation in PALB2 in Finnish cancer families. Nature 446:316-319.

Erkko H, Dowty JG, Nikkilä J, Syrjäkoski K, Mannermaa A, Pylkäs K, Southey MC, Holli K, Kallioniemi A, Jukkola-Vuorinen A et al. (2008) Penetrance analysis of the PALB2 c.1592delT founder mutation. Clin Cancer Res 14:4667-4671.

Evans T and Matulonis U (2017) PARP inhibitors in ovarian cancer: evidence, experience and clinical potential. Ther Adv Med Oncol 9:253-267.

Ewald IP, Ribeiro PL, Palmero EI, Cossio SL, Giugliani R and Ashton-Prolla P (2009) Genomic rearrangements in BRCA1 and BRCA2: A literature review. Genet Mol Biol 32:437-446.

Farmer H, McCabe N, Lord CJ, Tutt AN, Johnson DA, Richardson TB, Santarosa M, Dillon KJ, Hickson I, Knights C et al. (2005) Targeting the DNA repair defect in BRCA mutant cells as a therapeutic strategy. Nature 434:917-921.

Feilotter HE, Michel C, Uy P, Bathurst L and Davey S (2014) BRCA1 haploinsufficiency leads to altered expression of genes involved in cellular proliferation and development. PLoS One 9:e100068.

Ferrone CR, Levine DA, Tang LH, Allen PJ, Jarnagin W, Brennan MF, Offit K and Robson ME (2009) BRCA germline mutations in Jewish patients with pancreatic adenocarcinoma. $\mathrm{J}$ Clin Oncol 27:433-438.

Finch A, Beiner M, Lubinski J, Lynch HT, Moller P, Rosen B, Murphy J, Ghadirian P, Friedman E, Foulkes WD et al. (2006) Salpingo-oophorectomy and the risk of ovarian, fallopian tube, and peritoneal cancers in women with a BRCA1 or BRCA2 Mutation. JAMA 296:185-192.

Fong PC, Boss DS, Yap TA, Tutt A, Wu P, Mergui-Roelvink M, Mortimer P, Swaisland H, Lau A, O'Connor MJ et al. (2009) Inhibition of poly(ADP-ribose) polymerase in tumors from BRCA mutation carriers. N Engl J Med 361:123-134.

Ford D, Easton DF and Peto J (1995) Estimates of the gene frequency of BRCA1 and its contribution to breast and ovarian cancer incidence. Am J Hum Genet 57:1457-1462.

Foulkes WD, Stefansson IM, Chappuis PO, Bégin LR, Goffin JR, Wong N, Trudel M and Akslen LA (2003) Germline BRCA1 mutations and a basal epithelial phenotype in breast cancer. $\mathrm{J}$ Natl Cancer Inst 95:1482-1485.

Frank TS, Deffenbaugh AM, Reid JE, Hulick M, Ward BE, Lingenfelter B, Gumpper KL, Scholl T, Tavtigian SV, Pruss DR et al. (2002) Clinical characteristics of individuals with germline mutations in BRCA1 and BRCA2: analysis of 10,000 individuals. J Clin Oncol 20:1480-1490.

Freire BL, Homma TK, Funari MFA, Lerario AM, Leal AM, Velloso EDRP, Malaquias AC and Jorge AAL (2018) Homozygous loss of function BRCA1 variant causing a Fanconi-anemia-like phenotype, a clinical report and review of previous patients. Eur J Med Genet 61:130-133.

French JD, Dunn J, Smart CE, Manning N and Brown MA (2006) Disruption of BRCA1 function results in telomere lengthen- ing and increased anaphase bridge formation in immortalized cell lines. Genes Chromosomes Cancer 45:277-289.

Frey MK and Pothuri B (2017) Homologous recombination deficiency (HRD) testing in ovarian cancer clinical practice: a review of the literature. Gynecol Oncol Res Pract 4:4.

Gabai-Kapara E, Lahad A, Kaufman B, Friedman E, Segev S, Renbaum P, Beeri R, Gal M, Grinshpun-Cohen J, Djemal K et al. (2014) Population-based screening for breast and ovarian cancer risk due to BRCA1 and BRCA2. Proc Natl Acad Sci U S A 111:14205-14210.

García MJ, Fernández V, Osorio A, Barroso A, Llort G, Lázaro C, Blanco I, Caldés T, de la Hoya M, Ramón Y Cajal T et al. (2009) Analysis of FANCB and FANCN/PALB2 fanconi anemia genes in BRCA1/2-negative Spanish breast cancer families. Breast Cancer Res Treat 113:545-551.

Gorski JJ, Kennedy RD, Hosey AM and Harkin DP (2009) The complex relationship between BRCA1 and ERalpha in hereditary breast cancer. Clin Cancer Res 15:1514-1518.

Gowen LC, Johnson BL, Latour AM, Sulik KK and Koller BH (1996) Brca1 deficiency results in early embryonic lethality characterized by neuroepithelial abnormalities. Nat Genet 12:191-194.

Gudmundsdottir K and Ashworth A (2006) The roles of BRCA1 and BRCA2 and associated proteins in the maintenance of genomic stability. Oncogene 25:5864-5874.

Gupta A, Yang Q, Pandita RK, Hunt CR, Xiang T, Misri S, Zeng S, Pagan J, Jeffery J, Puc J et al. (2009) Cell cycle checkpoint defects contribute to genomic instability in PTEN deficient cells independent of DNA DSB repair. Cell Cycle 8:2198-2210.

Haanpää M, Pylkäs K, Moilanen JS and Winqvist R (2013) Evaluation of the need for routine clinical testing of PALB2 c.1592delT mutation in BRCA negative Northern Finnish breast cancer families. BMC Med Genet 14:82.

Hartley T, Cavallone L, Sabbaghian N, Silva-Smith R, Hamel N, Aleynikova O, Smith E, Hastings V, Pinto P, Tischkowitz M et al. (2014) Mutation analysis of PALB2 in BRCA1 and BRCA2-negative breast and/or ovarian cancer families from Eastern Ontario, Canada. Hered Cancer Clin Pract 12:19.

Heikkinen T, Kärkkäinen H, Aaltonen K, Milne RL, Heikkilä P, Aittomäki K, Blomqvist C and Nevanlinna H (2009) The breast cancer susceptibility mutation PALB2 1592delT is associated with an aggressive tumor phenotype. Clin Cancer Res 15:3214-3222.

Hemminki K and Vaittinen P (1999) Male breast cancer: Risk to daughters. Lancet 353:1186-1187.

Hill SJ, Rolland T, Adelmant G, Xia X, Owen MS, Dricot A, Zack TI, Sahni N, Jacob Y, Hao T et al. (2014) Systematic screening reveals a role for BRCA1 in the response to transcription-associated DNA damage. Genes Dev 28:1957-1975.

Holstege H, Joosse SA, van Oostrom CT, Nederlof PM, de Vries A and Jonkers J (2009) High incidence of protein-truncating TP53 mutations in BRCA1-related breast cancer. Cancer Res 69:3625-3633.

Honrado E, Benítez J and Palacios J (2005) The molecular pathology of hereditary breast cancer: Genetic testing and therapeutic implications. Mod Pathol 18:1305-1320.

Honrado E, Osorio A, Palacios J and Benitez J (2006) Pathology and gene expression of hereditary breast tumors associated with BRCA1, BRCA2 and CHEK2 gene mutations. Oncogene 25:5837-5845.

Hosey AM, Gorski JJ, Murray MM, Quinn JE, Chung WY, Stewart GE, James CR, Farragher SM, Mulligan JM, Scott AN et al. (2007) Molecular basis for estrogen receptor alpha deficiency 
in BRCA1-linked breast cancer. J Natl Cancer Inst 99:16831694.

Howlett NG, Taniguchi T, Olson S, Cox B, Waisfisz Q, De DieSmulders C, Persky N, Grompe M, Joenje H, Pals G et al. (2002) Biallelic inactivation of BRCA2 in Fanconi anemia. Science 297:606-609.

Israeli O, Gotlieb WH, Friedman E, Goldman B, Ben-Baruch G, Aviram-Goldring A and Rienstein S (2003) Familial vs sporadic ovarian tumors: characteristic genomic alterations analyzed by CGH. Gynecol Oncol 90:629-636.

Jaspers JE, Kersbergen A, Boon U, Sol W, van Deemter L, Zander SA, Drost R, Wientjens E, Ji J, Aly A et al. (2013) Loss of 53BP1 causes PARP inhibitor resistance in Brcal-mutated mouse mammary tumors. Cancer Discov 3:68-81.

Jones P, Altamura S, Boueres J, Ferrigno F, Fonsi M, Giomini C, Lamartina S, Monteagudo E, Ontoria JM, Orsale MV et al. (2009a) Discovery of 2-\{4-[(3S)-piperidin-3-yl]phenyl $\}$ 2H-indazole-7-carboxamide (MK-4827): a novel oral poly(ADP-ribose)polymerase (PARP) inhibitor efficacious in BRCA-1 and -2 mutant tumors. J Med Chem 52:7170-7185.

Jones S, Hruban RH, Kamiyama M, Borges M, Zhang X, Parsons DW, Lin JC, Palmisano E, Brune K, Jaffee EM et al. (2009b) Exomic sequencing identifies PALB2 as a pancreatic cancer susceptibility gene. Science 324:217.

Jonkers J, Meuwissen R, van der Gulden H, Peterse H, van der Valk $M$ and Berns A (2001) Synergistic tumor suppressor activity of BRCA2 and p53 in a conditional mouse model for breast cancer. Nat Genet 29:418-425.

Joosse SA (2012) BRCA1 and BRCA2: a common pathway of genome protection but different breast cancer subtypes. Nat Rev Cancer 12:372

Joukov V, Groen AC, Prokhorova T, Gerson R, White E, Rodriguez A, Walter JC and Livingston DM (2006) The BRCA1/BARD1 heterodimer modulates ran-dependent mitotic spindle assembly. Cell 127:539-552.

Jönsson G, Naylor TL, Vallon-Christersson J, Staaf J, Huang J, Ward MR, Greshock JD, Luts L, Olsson H, Rahman N et al. (2005) Distinct genomic profiles in hereditary breast tumors identified by array-based comparative genomic hybridization. Cancer Res 65:7612-7621.

Kamieniak MM, Muñoz-Repeto I, Rico D, Osorio A, Urioste M, García-Donas J, Hernando S, Robles-Díaz L, Ramón Y Cajal T, Cazorla A et al. (2013) DNA copy number profiling reveals extensive genomic loss in hereditary BRCA1 and BRCA2 ovarian carcinomas. Br J Cancer 108:1732-1742.

Kaufman B, Shapira-Frommer R, Schmutzler RK, Audeh MW, Friedlander M, Balmaña J, Mitchell G, Fried G, Stemmer SM, Hubert A et al. (2015) Olaparib monotherapy in patients with advanced cancer and a germline BRCA1/2 mutation. J Clin Oncol 33:244-250.

Kim MK, Zitzmann S, Westermann F, Arnold K, Brouwers S, Schwab M and Savelyeva L (2004) Increased rates of spontaneous sister chromatid exchange in lymphocytes of BRCA2+/- carriers of familial breast cancer clusters. Cancer Lett 210:85-94.

King TA, Li W, Brogi E, Yee CJ, Gemignani ML, Olvera N, Levine DA, Norton L, Robson ME, Offit K et al. (2007) Heterogenic loss of the wild-type BRCA allele in human breast tumorigenesis. Ann Surg Oncol 14:2510-2518.

Knudson AG (1971) Mutation and cancer: statistical study of retinoblastoma. Proc Natl Acad Sci U S A 68:820-823.

Konishi H, Mohseni M, Tamaki A, Garay JP, Croessmann S, Karnan S, Ota A, Wong HY, Konishi Y, Karakas B et al. (2011) Mutation of a single allele of the cancer susceptibility gene BRCA1 leads to genomic instability in human breast epithelial cells. Proc Natl Acad Sci U S A 108:17773-17778.

Krammer J, Pinker-Domenig K, Robson ME, Gönen M, BernardDavila B, Morris EA, Mangino DA and Jochelson MS (2017) Breast cancer detection and tumor characteristics in BRCA1 and BRCA2 mutation carriers. Breast Cancer Res Treat 163:565-571.

Kuchenbaecker KB, Hopper JL, Barnes DR, Phillips KA, Mooij TM, Roos-Blom MJ, Jervis S, van Leeuwen FE, Milne RL, Andrieu N et al. (2017) Risks of Breast, Ovarian, and Contralateral Breast Cancer for BRCA1 and BRCA2 Mutation Carriers. JAMA 317:2402-2416.

Lakhani SR, Jacquemier J, Sloane JP, Gusterson BA, Anderson TJ, van de Vijver MJ, Farid LM, Venter D, Antoniou A, StorferIsser A et al. (1998) Multifactorial analysis of differences between sporadic breast cancers and cancers involving BRCA1 and BRCA2 mutations. J Natl Cancer Inst 90:1138-1145.

Lakhani SR, Reis-Filho JS, Fulford L, Penault-Llorca F, van der Vijver M, Parry S, Bishop T, Benitez J, Rivas C, Bignon YJ et al. (2005) Prediction of BRCA1 status in patients with breast cancer using estrogen receptor and basal phenotype. Clin Cancer Res 11:5175-5180.

Levy-Lahad E and Friedman E (2007) Cancer risks among BRCA1 and BRCA2 mutation carriers. Br J Cancer 96:11-15.

Lieber MR (2010) The mechanism of double-strand DNA break repair by the nonhomologous DNA end-joining pathway. Annu Rev Biochem 79:181-211.

Lim E, Vaillant F, Wu D, Forrest NC, Pal B, Hart AH, AsselinLabat ML, Gyorki DE, Ward T, Partanen A et al. (2009) Aberrant luminal progenitors as the candidate target population for basal tumor development in BRCA1 mutation carriers. Nat Med 15:907-913.

Liu G, Yang D, Sun Y, Shmulevich I, Xue F, Sood AK and Zhang W (2012) Differing clinical impact of BRCA1 and BRCA2 mutations in serous ovarian cancer. Pharmacogenomics 13:1523-1535.

Livraghi L and Garber JE (2015) PARP inhibitors in the management of breast cancer: current data and future prospects. BMC Med 13:188.

Lord CJ and Ashworth A (2013) Mechanisms of resistance to therapies targeting BRCA-mutant cancers. Nat Med 19:1381-1388.

Lord CJ and Ashworth A (2016) BRCAness revisited. Nat Rev Cancer 16:110-120.

Lord CJ and Ashworth A (2017) PARP inhibitors: Synthetic lethality in the clinic. Science 355:1152-1158.

Lynch BJ, Holden JA, Buys SS, Neuhausen SL and Gaffney DK (1998) Pathobiologic characteristics of hereditary breast cancer. Hum Pathol 29:1140-1144.

Manié E, Vincent-Salomon A, Lehmann-Che J, Pierron G, Turpin E, Warcoin M, Gruel N, Lebigot I, Sastre-Garau X, Lidereau $\mathrm{R}$ et al. (2009) High frequency of TP53 mutation in BRCA1 and sporadic basal-like carcinomas but not in BRCA1 luminal breast tumors. Cancer Res 69:663-671.

Mao Z, Bozzella M, Seluanov A and Gorbunova V (2008) DNA repair by nonhomologous end joining and homologous recombination during cell cycle in human cells. Cell Cycle 7:29022906.

Martins FC, De S, Almendro V, Gönen M, Park SY, Blum JL, Herlihy W, Ethington G, Schnitt SJ, Tung N et al. (2012) Evolutionary pathways in BRCA1-associated breast tumors. Cancer Discov 2:503-511.

Mathew CG (2006) Fanconi anaemia genes and susceptibility to cancer. Oncogene 25:5875-5884. 
Mavaddat N, Barrowdale D, Andrulis IL, Domchek SM, Eccles D, Nevanlinna H, Ramus SJ, Spurdle A, Robson M, Sherman M et al. (2012) Pathology of breast and ovarian cancers among BRCA1 and BRCA2 mutation carriers: results from the Consortium of Investigators of Modifiers of BRCA1/2 (CIMBA). Cancer Epidemiol Biomarkers Prev 21:134-147.

Maxwell KN, Wubbenhorst B, Wenz BM, De Sloover D, Pluta J, Emery L, Barrett A, Kraya AA, Anastopoulos IN, Yu S et al. (2017) BRCA locus-specific loss of heterozygosity in germline BRCA1 and BRCA2 carriers. Nat Commun 8:319.

Melchor L, Honrado E, García MJ, Alvarez S, Palacios J, Osorio A, Nathanson KL and Benítez J (2008) Distinct genomic aberration patterns are found in familial breast cancer associated with different immunohistochemical subtypes. Oncogene 27:3165-3175.

Metzger MJ, Stoddard BL and Monnat RJ (2013) PARP-mediated repair, homologous recombination, and back-up non-homologous end joining-like repair of single-strand nicks. DNA Repair 12:529-534.

Meyer S, Tischkowitz M, Chandler K, Gillespie A, Birch JM and Evans DG (2014) Fanconi anaemia, BRCA2 mutations and childhood cancer: a developmental perspective from clinical and epidemiological observations with implications for genetic counselling. J Med Genet 51:71-75.

Miki Y, Swensen J, Shattuck-Eidens D, Futreal PA, Harshman K, Tavtigian S, Liu Q, Cochran C, Bennett LM and Ding W (1994) A strong candidate for the breast and ovarian cancer susceptibility gene BRCA1. Science 266:66-71.

Mirza MR, Monk BJ, Herrstedt J, Oza AM, Mahner S, Redondo A, Fabbro M, Ledermann JA, Lorusso D, Vergote I et al. (2016) Niraparib maintenance therapy in platinum-sensitive, recurrent ovarian cancer. N Engl J Med 375:2154-2164.

Molyneux G, Geyer FC, Magnay FA, McCarthy A, Kendrick H, Natrajan R, Mackay A, Grigoriadis A, Tutt A, Ashworth A et al. (2010) BRCA1 basal-like breast cancers originate from luminal epithelial progenitors and not from basal stem cells. Cell Stem Cell 7:403-417.

Moynahan ME (2002) The cancer connection: BRCA1 and BRCA2 tumor suppression in mice and humans. Oncogene 21:89949007.

Moynahan ME, Chiu JW, Koller BH and Jasin M (1999) Brca1 controls homology-directed DNA repair. Mol Cell 4:511518.

Moynahan ME, Pierce AJ and Jasin M (2001) BRCA2 is required for homology-directed repair of chromosomal breaks. Mol Cell 7:263-272.

Narod SA and Foulkes WD (2004) BRCA1 and BRCA2: 1994 and beyond. Nat Rev Cancer 4:665-676.

Natrajan R, Mackay A, Lambros MB, Weigelt B, Wilkerson PM, Manie E, Grigoriadis A, A'hern R, van der Groep P, Kozarewa I et al. (2012) A whole-genome massively parallel sequencing analysis of BRCA1 mutant oestrogen receptornegative and -positive breast cancers. J Pathol 227:29-41.

Network CGAR (2011) Integrated genomic analyses of ovarian carcinoma. Nature 474:609-615.

Network CGA (2012) Comprehensive molecular portraits of human breast tumours. Nature 490:61-70.

Nguyen-Dumont T, Hammet F, Mahmoodi M, Tsimiklis H, Teo ZL, Li R, Pope BJ, Terry MB, Buys SS, Daly M et al. (2015) Mutation screening of PALB2 in clinically ascertained families from the Breast Cancer Family Registry. Breast Cancer Res Treat 149:547-554.
Nielsen FC, van Overeem Hansen T and Sørensen CS (2016) Hereditary breast and ovarian cancer: new genes in confined pathways. Nat Rev Cancer 16:599-612.

Nik-Zainal S, Alexandrov LB, Wedge DC, Van Loo P, Greenman CD, Raine K, Jones D, Hinton J, Marshall J, Stebbings LA et al. (2012) Mutational processes molding the genomes of 21 breast cancers. Cell 149:979-993.

Nik-Zainal S, Davies H, Staaf J, Ramakrishna M, Glodzik D, Zou X, Martincorena I, Alexandrov LB, Martin S, Wedge DC et al. (2016) Landscape of somatic mutations in 560 breast cancer whole-genome sequences. Nature 534:47-54.

Nikkilä J, Parplys AC, Pylkäs K, Bose M, Huo Y, Borgmann K, Rapakko K, Nieminen P, Xia B, Pospiech H et al. (2013) Heterozygous mutations in PALB2 cause DNA replication and damage response defects. Nat Commun 4:2578.

Norquist BM, Garcia RL, Allison KH, Jokinen CH, Kernochan LE, Pizzi CC, Barrow BJ, Goff BA and Swisher EM (2010) The olecular pathogenesis of hereditary ovarian carcinoma: al terations in the tubal epithelium of women with BRCA1 and BRCA2 mutations. Cancer 116:5261-5271.

Obermeier K, Sachsenweger J, Friedl TW, Pospiech H, Winqvist R and Wiesmüller L (2015) Heterozygous PALB2 c.1592delT mutation channels DNA double-strand break repair into error-prone pathways in breast cancer patients. Oncogene 35:3796-3806.

Osorio A, de la Hoya M, Rodríguez-López R, Martínez-Ramírez A, Cazorla A, Granizo JJ, Esteller M, Rivas C, Caldés T and Benítez J (2002) Loss of heterozygosity analysis at the BRCA loci in tumor samples from patients with familial breast cancer. Int J Cancer 99:305-309.

Ottini L, Rizzolo P, Zanna I, Falchetti M, Masala G, Ceccarelli K, Vezzosi V, Gulino A, Giannini G, Bianchi S et al. (2009) BRCA1/BRCA2 mutation status and clinical-pathologic features of 108 male breast cancer cases from Tuscany: A population-based study in central Italy. Breast Cancer Res Treat 116:577-586.

Palacios J, Honrado E, Osorio A, Cazorla A, Sarrió D, Barroso A, Rodríguez S, Cigudosa JC, Diez O, Alonso C et al. (2003) Immunohistochemical characteristics defined by tissue microarray of hereditary breast cancer not attributable to BRCA1 or BRCA 2 mutations: differences from breast carcinomas arising in BRCA1 and BRCA2 mutation carriers. Clin Cancer Res 9:3606-3614.

Palacios J, Honrado E, Osorio A, Cazorla A, Sarrió D, Barroso A, Rodríguez S, Cigudosa JC, Diez O, Alonso C et al. (2005) Phenotypic characterization of BRCA1 and BRCA2 tumors based in a tissue microarray study with 37 immunohistochemical markers. Breast Cancer Res Treat 90:5-14.

Pathania S, Bade S, Le Guillou M, Burke K, Reed R, BowmanColin C, Su Y, Ting DT, Polyak K, Richardson AL et al. (2014) BRCA1 haploinsufficiency for replication stress suppression in primary cells. Nat Commun 5:5496.

Peng G and Lin SY (2011) Exploiting the homologous recombination DNA repair network for targeted cancer therapy. World J Clin Oncol 2:73-79.

Phuah SY, Looi LM, Hassan N, Rhodes A, Dean S, Taib NA, Yip CH and Teo SH (2012) Triple-negative breast cancer and PTEN (phosphatase and tensin homologue) loss are predictors of BRCA1 germline mutations in women with earlyonset and familial breast cancer, but not in women with isolated late-onset breast cancer. Breast Cancer Res 14:R142.

Plevova P, Cerna D, Balcar A, Foretova L, Zapletalova J, Silhanova E, Curik R and Dvorackova J (2010) CCND1 and ZNF217 gene amplification is equally frequent in BRCA1 and BRCA2 
associated and non-BRCA breast cancer. Neoplasma 57:325-32.

Plon SE, Eccles DM, Easton D, Foulkes WD, Genuardi M, Greenblatt MS, Hogervorst FB, Hoogerbrugge N, Spurdle AB, Tavtigian SV et al. (2008) Sequence variant classification and reporting: recommendations for improving the interpretation of cancer susceptibility genetic test results. Hum Mutat 29:1282-1291.

Polak P, Kim J, Braunstein LZ, Karlic R, Haradhavala NJ, Tiao G, Rosebrock D, Livitz D, Kübler K, Mouw KW et al. (2017) A mutational signature reveals alterations underlying deficient homologous recombination repair in breast cancer. Nat Genet 49:1476-1486.

Proia TA, Keller PJ, Gupta PB, Klebba I, Jones AD, Sedic M, Gilmore H, Tung N, Naber SP, Schnitt S et al. (2011) Genetic predisposition directs breast cancer phenotype by dictating progenitor cell fate. Cell Stem Cell 8:149-163.

Pujade-Lauraine E, Ledermann JA, Selle F, Gebski V, Penson RT, Oza AM, Korach J, Huzarski T, Poveda A, Pignata S et al. (2017) Olaparib tablets as maintenance therapy in patients with platinum-sensitive, relapsed ovarian cancer and a BRCA1/2 mutation (SOLO2/ENGOT-Ov21): A doubleblind, randomised, placebo-controlled, phase 3 trial. Lancet Oncol 18:1274-1284.

Qian Y, Mancini-DiNardo D, Judkins T, Cox HC, Brown K, Elias M, Singh N, Daniels C, Holladay J, Coffee B et al. (2017) Identification of pathogenic retrotransposon insertions in cancer predisposition genes. Cancer Genet 216-217:159-169.

Rahman N, Seal S, Thompson D, Kelly P, Renwick A, Elliott A, Reid S, Spanova K, Barfoot R, Chagtai T et al. (2007) PALB2, which encodes a BRCA2-interacting protein, is a breast cancer susceptibility gene. Nat Genet 39:165-167.

Rantakari P, Nikkilä J, Jokela H, Ola R, Pylkäs K, Lagerbohm H, Sainio K, Poutanen M and Winqvist R (2010) Inactivation of Palb2 gene leads to mesoderm differentiation defect and early embryonic lethality in mice. Hum Mol Genet 19:3021-3029.

Ready K, Gutierrez-Barrera AM, Amos C, Meric-Bernstam F, Lu K, Hortobagyi G and Arun B (2011) Cancer risk management decisions of women with BRCA1 or BRCA2 variants of uncertain significance. Breast J 17:210-212.

Reid S, Renwick A, Seal S, Baskcomb L, Barfoot R, Jayatilake H, Pritchard-Jones K, Stratton MR, Ridolfi-Lüthy A, Rahman N et al. (2005) Biallelic BRCA2 mutations are associated with multiple malignancies in childhood including familial Wilms tumour. J Med Genet 42:147-151.

Reid S, Schindler D, Hanenberg H, Barker K, Hanks S, Kalb R, Neveling K, Kelly P, Seal S, Freund M et al. (2007) Biallelic mutations in PALB2 cause Fanconi anemia subtype FA-N and predispose to childhood cancer. Nat Genet 39:162-164.

Riaz N, Blecua P, Lim RS, Shen R, Higginson DS, Weinhold N, Norton L, Weigelt B, Powell SN and Reis-Filho JS (2017) Pan-cancer analysis of bi-allelic alterations in homologous recombination DNA repair genes. Nat Commun 8:857.

Roy R, Chun J and Powell SN (2012) BRCA1 and BRCA2: different roles in a common pathway of genome protection. Nat Rev Cancer 12:68-78.

Saal LH, Gruvberger-Saal SK, Persson C, Lövgren K, Jumppanen M, Staaf J, Jönsson G, Pires MM, Maurer M, Holm K et al. (2008) Recurrent gross mutations of the PTEN tumor suppressor gene in breast cancers with deficient DSB repair. Nat Genet 40:102-107.

Sakai W, Swisher EM, Karlan BY, Agarwal MK, Higgins J, Friedman C, Villegas E, Jacquemont C, Farrugia DJ, Couch FJ et al. (2008) Secondary mutations as a mechanism of cisplatin resistance in BRCA2-mutated cancers. Nature 451:11161120.

Sandhu SK, Schelman WR, Wilding G, Moreno V, Baird RD, Miranda S, Hylands L, Riisnaes R, Forster M, Omlin A et al. (2013) The poly(ADP-ribose) polymerase inhibitor niraparib (MK4827) in BRCA mutation carriers and patients with sporadic cancer: a phase 1 dose-escalation trial. Lancet Oncol 14:882-892.

Santarosa M and Ashworth A (2004) Haploinsufficiency for tumour suppressor genes: When you don't need to go all the way. Biochim Biophys Acta 1654:105-122.

Savage KI, Matchett KB, Barros EM, Cooper KM, Irwin GW, Gorski JJ, Orr KS, Vohhodina J, Kavanagh JN, Madden AF et al. (2014) BRCA1 deficiency exacerbates estrogen-induced DNA damage and genomic instability. Cancer Res 74:2773-2784.

Savelyeva L, Claas A, Matzner I, Schlag P, Hofmann W, Scherneck S, Weber B and Schwab M (2001) Constitutional genomic instability with inversions, duplications, and amplifications in 9p23-24 in BRCA2 mutation carriers. Cancer Res 61:51795185.

Sawyer SL, Tian L, Kähkönen M, Schwartzentruber J, Kircher M, Majewski J, Dyment DA, Innes AM, Boycott KM, Moreau LA et al. (2015) Biallelic mutations in BRCA1 cause a new Fanconi anemia subtype. Cancer Discov 5:135-142.

Schlacher K, Christ N, Siaud N, Egashira A, Wu H and Jasin M (2011) Double-strand break repair-independent role for BRCA2 in blocking stalled replication fork degradation by MRE11. Cell 145:529-542.

Sedic M, Skibinski A, Brown N, Gallardo M, Mulligan P, Martinez P, Keller PJ, Glover E, Richardson AL, Cowan J et al. (2015) Haploinsufficiency for BRCA1 leads to cell-type-specific genomic instability and premature senescence. Nat Commun 6:7505.

Seo A, Steinberg-Shemer O, Unal S, Casadei S, Walsh T, Gumruk F, Shalev S, Shimamura A, Akarsu NA, Tamary H et al. (2018) Mechanism for survival of homozygous nonsense mutations in the tumor suppressor gene. Proc Natl Acad Sci U S A 115:5241-5246.

Sharan SK, Morimatsu M, Albrecht U, Lim DS, Regel E, Dinh C, Sands A, Eichele G, Hasty P and Bradley A (1997) Embryonic lethality and radiation hypersensitivity mediated by Rad51 in mice lacking Brca2. Nature 386:804-810.

Shen SX, Weaver Z, Xu X, Li C, Weinstein M, Chen L, Guan XY, Ried T and Deng CX (1998) A targeted disruption of the murine Brcal gene causes gamma-irradiation hypersensitivity and genetic instability. Oncogene 17:3115-3124.

Shen WH, Balajee AS, Wang J, Wu H, Eng C, Pandolfi PP and Yin Y (2007) Essential role for nuclear PTEN in maintaining chromosomal integrity. Cell 128:157-170.

Shen Y, Rehman FL, Feng Y, Boshuizen J, Bajrami I, Elliott R, Wang B, Lord CJ, Post LE and Ashworth A (2013) BMN 673, a novel and highly potent PARP $1 / 2$ inhibitor for the treatment of human cancers with DNA repair deficiency. Clin Cancer Res 19:5003-5015.

Slater EP, Langer P, Niemczyk E, Strauch K, Butler J, Habbe N, Neoptolemos JP, Greenhalf W and Bartsch DK (2010) PALB2 mutations in European familial pancreatic cancer families. Clin Genet 78:490-494.

Sonoda E, Hochegger H, Saberi A, Taniguchi Y and Takeda S (2006) Differential usage of non-homologous end-joining and homologous recombination in double strand break repair. DNA Repair 5:1021-1029. 
Sorlie T, Tibshirani R, Parker J, Hastie T, Marron JS, Nobel A, Deng S, Johnsen H, Pesich R, Geisler S et al. (2003) Repeated observation of breast tumor subtypes in independent gene expression data sets. Proc Natl Acad Sci U S A 100:8418-8423.

Southey MC, Teo ZL and Winship I (2013) PALB2 and breast cancer: Ready for clinical translation! Appl Clin Genet 6:43-52.

Stefansson OA, Jonasson JG, Olafsdottir K, Bjarnason H, Th Johannsson $\mathrm{O}$, Bodvarsdottir SK, Valgeirsdottir $\mathrm{S}$ and Eyfjord JE (2011) Genomic and phenotypic analysis of BRCA2 mutated breast cancers reveals co-occurring changes linked to progression. Breast Cancer Res 13:R95.

Stracker TH, Roig I, Knobel PA and Marjanovic M (2013) The ATM signaling network in development and disease. Front Genet 4:37.

Struewing JP, Hartge P, Wacholder S, Baker SM, Berlin M, McAdams M, Timmerman MM, Brody LC and Tucker MA (1997) The risk of cancer associated with specific mutations of BRCA1 and BRCA2 among Ashkenazi Jews. N Engl J Med 336:1401-1408.

Sverdlov RS, Barshack I, Bar Sade RB, Baruch RG, HirshYehezkel G, Dagan E, Feinmesser M, Figer A and Friedman E (2000) Genetic analyses of male breast cancer in Israel. Genet Test 4:313-317.

Swisher EM, Lin KK, Oza AM, Scott CL, Giordano H, Sun J, Konecny GE, Coleman RL, Tinker AV, O'Malley DM et al. (2017) Rucaparib in relapsed, platinum-sensitive high-grade ovarian carcinoma (ARIEL2 Part 1): An international, multicentre, open-label, phase 2 trial. Lancet Oncol 18:75-87.

Sy SM, Huen MS and Chen J (2009) PALB2 is an integral component of the BRCA complex required for homologous recombination repair. Proc Natl Acad Sci U S A 106:7155-7160.

Tavtigian SV, Simard J, Rommens J, Couch F, Shattuck-Eidens D, Neuhausen S, Merajver S, Thorlacius S, Offit K, StoppaLyonnet D et al. (1996) The complete BRCA2 gene and mutations in chromosome 13q-linked kindreds. Nat Genet 12:333-337.

Teng LS, Zheng Y and Wang HH (2008) BRCA1/2 associated hereditary breast cancer. J Zhejiang Univ Sci B 9:85-89.

Teo ZL, Provenzano E, Dite GS, Park DJ, Apicella C, Sawyer SD, James PA, Mitchell G, Trainer AH, Lindeman GJ et al. (2013) Tumour morphology predicts PALB2 germline mutation status. Br J Cancer 109:154-163.

Thompson D, Easton DF and Consortium BCL (2002) Cancer Incidence in BRCA1 mutation carriers. J Natl Cancer Inst 94:1358-1365.

Thorlacius S, Sigurdsson S, Bjarnadottir H, Olafsdottir G, Jonasson JG, Tryggvadottir L, Tulinius H and Eyfjörd JE (1997) Study of a single BRCA2 mutation with high carrier frequency in a small population. Am J Hum Genet 60:1079-1084.

Tischkowitz MD and Hodgson SV (2003) Fanconi anaemia. J Med Genet 40:1-10

Tischkowitz M, Xia B, Sabbaghian N, Reis-Filho JS, Hamel N, Li G, van Beers EH, Li L, Khalil T, Quenneville LA et al. (2007) Analysis of PALB2/FANCN-associated breast cancer families. Proc Natl Acad Sci U S A 104:6788-6793.

Tischkowitz MD, Sabbaghian N, Hamel N, Borgida A, Rosner C, Taherian N, Srivastava A, Holter S, Rothenmund H, Ghadirian P et al. (2009) Analysis of the gene coding for the BRCA2-interacting protein PALB2 in familial and sporadic pancreatic cancer. Gastroenterology 137:1183-1186.

Toland AE and Andreassen PR (2017) DNA repair-related functional assays for the classification of BRCA1 and BRCA2 variants: a critical review and needs assessment. J Med Genet 54:721-731.
Tsuda H, Fukutomi T and Hirohashi S (1995) Pattern of gene alterations in intraductal breast neoplasms associated with histological type and grade. Clin Cancer Res 1:261-267.

Tung N, Miron A, Schnitt SJ, Gautam S, Fetten K, Kaplan J, Yassin Y, Buraimoh A, Kim JY, Szász AM et al. (2010) Prevalence and predictors of loss of wild type BRCA1 in estrogen receptor positive and negative BRCA1-associated breast cancers. Breast Cancer Res 12:R95.

Tutt AN, Lord CJ, McCabe N, Farmer H, Turner N, Martin NM, Jackson SP, Smith GC and Ashworth A (2005) Exploiting the DNA repair defect in BRCA mutant cells in the design of new therapeutic strategies for cancer. Cold Spring Harb Symp Quant Biol 70:139-148.

Tutt A, Robson M, Garber JE, Domchek SM, Audeh MW, Weitzel JN, Friedlander M, Arun B, Loman N, Schmutzler RK et al. (2010) Oral poly(ADP-ribose) polymerase inhibitor olaparib in patients with BRCA1 or BRCA2 mutations and advanced breast cancer: a proof-of-concept trial. Lancet 376:235-244.

van der Groep P, van der Wall E and van Diest PJ (2011) Pathology of hereditary breast cancer. Cell Oncol 34:71-88.

Vaziri SA, Tubbs RR, Darlington G and Casey G (2001) Absence of CCND1 gene amplification in breast tumours of BRCA1 mutation carriers. Mol Pathol 54:259-263

Venkitaraman AR (2001) Functions of BRCA1 and BRCA2 in the biological response to DNA damage. J Cell Sci 114:35913598.

Venkitaraman AR (2014) Cancer suppression by the chromosome custodians, BRCA1 and BRCA2. Science 343:1470-1475.

Vousden KH and Prives C (2009) Blinded by the light: The growing complexity of p53. Cell 137:413-431.

Walsh CS, Ogawa S, Scoles DR, Miller CW, Kawamata N, Narod SA, Koeffler HP and Karlan BY (2008) Genome-wide loss of heterozygosity and uniparental disomy in BRCA1/2-associated ovarian carcinomas. Clin Cancer Res 14:7645-7651.

Wang HC, Chou WC, Shieh SY and Shen CY (2006) Ataxia telangiectasia mutated and checkpoint kinase 2 regulate BRCA1 to promote the fidelity of DNA end-joining. Cancer Res 66:1391-1400.

Wang ZQ, Auer B, Stingl L, Berghammer H, Haidacher D, Schweiger M and Wagner EF (1995) Mice lacking ADPRT and poly(ADP-ribosyl)ation develop normally but are susceptible to skin disease. Genes Dev 9:509-520.

Weiss JR, Moysich KB and Swede H (2005) Epidemiology of male breast cancer. Cancer Epidemiol Biomarkers Prev 14:20-26.

Welcsh PL and King MC (2001) BRCA1 and BRCA2 and the genetics of breast and ovarian cancer. Hum Mol Genet 10:705713.

Whittemore AS, Gong G and Itnyre J (1997) Prevalence and contribution of BRCA1 mutations in breast cancer and ovarian cancer: results from three U.S. population-based case-control studies of ovarian cancer. Am J Hum Genet 60:496-504.

Xia B, Sheng Q, Nakanishi K, Ohashi A, Wu J, Christ N, Liu X, Jasin M, Couch FJ and Livingston DM (2006) Control of BRCA2 cellular and clinical functions by a nuclear partner, PALB2. Mol Cell 22:719-729.

Xia F, Taghian DG, DeFrank JS, Zeng ZC, Willers H, Iliakis G and Powell SN (2001) Deficiency of human BRCA2 leads to impaired homologous recombination but maintains normal nonhomologous end joining. Proc Natl Acad Sci U S A 98:8644-8649.

Ye Q, Hu YF, Zhong H, Nye AC, Belmont AS and Li R (2001) BRCA1-induced large-scale chromatin unfolding and allelespecific effects of cancer-predisposing mutations. J Cell Biol 155:911-921. 
Yu VP, Koehler M, Steinlein C, Schmid M, Hanakahi LA, van Gool AJ, West SC and Venkitaraman AR (2000) Gross chromosomal rearrangements and genetic exchange between nonhomologous chromosomes following BRCA2 inactivation. Genes Dev 14:1400-1406.

Yuan SS, Lee SY, Chen G, Song M, Tomlinson GE and Lee EY (1999) BRCA2 is required for ionizing radiation-induced assembly of Rad51 complex in vivo. Cancer Res 59:3547-3551.

Zhang F, Ma J, Wu J, Ye L, Cai H, Xia B and Yu X (2009) PALB2 links BRCA1 and BRCA2 in the DNA-damage response. Curr Biol 19:524-529.

Zhu Q, Pao GM, Huynh AM, Suh H, Tonnu N, Nederlof PM, Gage FH and Verma IM (2011) BRCA1 tumour suppression occurs via heterochromatin-mediated silencing. Nature 477:179-184.

\section{Internet Resources}

NCCN (2017) Clinical Practice Guidelines in Oncology. Genetic/Familial High-Risk Assessment: Breast and Ovarian. Hereditary Breast and/or Ovarian Cancer. Version 1.2018. http://www.nccn.org - NCCN - National Comprehensive Cancer Network.

Associate Editor: Mariluce Riegel

License information: This is an open-access article distributed under the terms of the Creative Commons Attribution License (type CC-BY), which permits unrestricted use, distribution and reproduction in any medium, provided the original article is properly cited. 